Coal-Fueled High-Speed Diesel Engine Development Task 2 -- Market Assessment and Economic Analysis

Topical Report

December 1991

Work Performed Under Contract No.: DE-AC21-90MC27222

For

U.S. Department of Energy

Office of Fossil Energy

Morgantown Energy Technology Center

Morgantown, West Virginia

By

Detroit Diesel Corporation

Detroit, Michigan 


\section{DISCLAIMER}

This report was prepared as an account of work sponsored by an agency of the United States Government. Neither the United States Government nor any agency thereof, nor any of their employees, makes any warranty, express or implied, or assumes any legal liability or responsibility for the accuracy, completeness, or usefulness of any information, apparatus, product, or process disclosed, or represents that its use would not infringe privately owned rights. Reference herein to any specific commercial product, process, or service by trade name, trademark, manufacturer, or otherwise does not necessarily constitute or imply its endorsement, recommendation, or favoring by the United States Government or any agency thereof. The views and opinions of authors expressed herein do not necessarily state or reflect those of the United States Government or any agency thereof.

This report has been reproduced directly from the best available copy.

Available to DOE and DOE contractors from the Office of Scientific and Technical Information, P.O. Box 62, Oak Ridge, TN 37831; prices available from (615)576-8401,

Available to the public from the National Technical Information Service, U.S. Department of Commerce, 5285 Port Royal Rd., Springfield, VA 22161. 


\title{
Coal-Fueled High-Speed Diesel Engine Development
} Task 2 -- Market Assessment and Economic Analysis

\author{
Topical Report
}

Work Performed Under Contract No.: DE-AC21-90MC27222

\author{
For \\ U.S. Department of Energy \\ Office of Fossil Energy \\ Morgantown Energy Technology Center \\ P.O. Box 880 \\ Morgantown, West Virginia 26507-0880 \\ By \\ Detroit Diesel Corporation \\ 13400 Outer Drive, West \\ Detroit, Michigan 48239-4001
}

December 1991 


\section{ACKNOWLEDGMENTS}

Progran Manager:

R. M. Kakwani

Technical Contributors: Arthur D. Little, Inc.

R. P. Wilson, Jr.

Detroit Diesel Corporation

R. M. Kakwani

R. E. Winsor 


\section{Table of Contents}

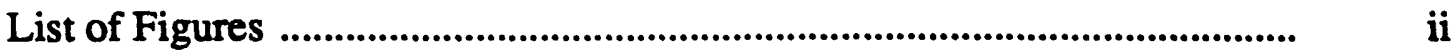

List of Tables .................................................................................................... ii

Executive Summary .................................................................................... S-1

1.0 Objectives and Approach ........................................................................ 1

2.0 Selection of Engine Applications ............................................................... 2

2.1 Candidate 300-2500 hp Engine Applications ....................................... 2

2.2 Selection Criteria for Coal Fuel Feasibility ............................................. 2

2.3 Screening of Engine Applications ......................................................... 3

3.0 Mine-Haul Truck Application ........................................................................ 5

3.1 Description of Mine-Haul Truck (170-240 ton) ...................................... 5

3.2 Schematic Design of Coal Engine System - Mine-Haul Truck ................. 5

3.3 Existing Mine-Haul Trucks - Population and Sales by Mine Type .......... 11

3.4 Duty Cycle, Engine Efficiency and Overall Fuel Usage .......................... 12

3.5 Mine locations and Coal Slurry Logistics ................................................ $\quad 14$

3.6 Baseline Operating Costs/Engine Parts Replacement ............................ $\quad 14$

4.0 Inland Waterway Towboat Application ............................................................ 15

4.1 Description of Towboat Application ................................................... 15

4.2 Schematic Design of Coal Engine System - Towboat ............................ 15

4.3 Existing Towboat Engines - Population and Sales ................................. 15

4.4 Duty Cycle and Overall Fuel Usage ...................................................... 19

4.5 Towboat Operating Routes and Coal Slurry Logistics ............................ 21

4.6 Baseline Operating Costs/Engine Parts Replacement ............................. $\quad 22$

5.0 Emission Control System for Mine-Haul Truck and Towboat Engines ......... $\quad 23$

6.0 Engine Spreadsheet Model for Lifecycle Costs ............................................. 26

6.1 Input Definition ................................................................................. 27

6.2 Coal Slurry Cost Summary .................................................................. $\quad 30$

6.3 Coal Engine Capital Cost ................................................................... $\quad 30$

6.4 Coal Engine Maintenance Costs ....................................................... 31

6.5 Coal Engine Fuel Cost ....................................................................... 34

6.6 Total Coal Fired Engine Capital and Operating Costs ........................... $\quad 34$

6.7 Oil-Fired Engine Capital Costs ............................................................... $\quad 35$

6.8 Oil-Fired Engine Maintenance Costs .................................................. 36

6.9 Total Oil-Fired Engine Capital and Operating Costs ............................... 38

7.0 Analysis of Economic Feasibility ............................................................. 39

7.1 Spreadsheet Input for Parametric Runs ................................................... 39

7.2 Results for Mine-Haul Truck Application ........................................... $\quad 42$

7.3 Results for Inland Waterway Tow Boat ............................................. 46

7.4 Diesel Fuel Use Effects .................................................................. 49

7.5 Conclusions ............................................................................... 51 
List of Figures

Figure 1: Typical Mine-Haul Trucks in Operation .......................................... 6

Figure 2: $\quad$ Mine-Haul Truck (240-Ton Capacity) Showing Operators for

Scale

Figure 3: Mine-Haul Trucks in Operation

Figure 4: Major Dimensions of Typical Mine-Haul Truck

Figure 5: Emission Control Device for Coal Fired Diesel Mine-Haul Truck

(2,000 HP)

Figure 6: Some Regions with large Population of Miine-Haul Trucks

Figure 7: Engine Performance Curve, DDC Model 16V-149T1

Marine-Continuous

Figure 8: $\quad$ 1,800 HP Viking Class Towboat

Figure 9: Emission Control Device for Coal-Fired Diesel Towboat (1,000 HP $\times 2$ 2)

Figure 10: Actual Data Showing Distribution of Engine Operating Time by RPM

Figure 11: Coal Cleaning Cost Effects for a Mine-Haul Truck with a Coal Engine Efficiency $=28 \%$

Figure 12: Coal Cleaning Cost Effects for a Mine-Haul Truck with a Coal Engine Efficiency $=34 \%$

Figure 13: Nozzle Life Cost Effects for a Mine-Haul Truck .............................. 44

Figure 14: Interest Rate Effects for a Mine-Haul Truck ...................................... $\quad 45$

Figure 15: Coal Cleaning Cost Effects for an Inland Tow Boat ........................ 47

Figure 16: Nozzle Life Cost Effects for a Mine-Haul Truck ............................. 48

Figure 17: Interest Rate Effects for an Inland Tow Boat ..................................

Figure 18: Diesel Fuel Use Effects on Annual Savings for Inland Tow Boat

Figure 19: Diesel Fuel Use Effects for an Inland Tow Boat with a Coal

Engine Efficiency $=34 \%$ 
Table 1: Evaluation Criteria for DDC Coal Engine Application ...................... 4

Table 2: $\quad$ Fifteen Leading Copper-Producing Mines in the United States in 1989 , in Order of Output .................................................................. 12

Table 3: $\quad$ Major U.S. Coal Mines, 1989 (Million Short Tons) ......................... $\quad 12$

Table 4: Inland Waterway Towboat Engine Database Results ....................... $\quad 19$

Table 5: Emission Control System Design Assumptions ................................ 23

Table 6: Estimated Equipment Cost ................................................................... 24

Table 7: User Input Parameters ..................................................................... 27

Table 8: $\quad$ Slurry Cost Summary ........................................................................ $\quad 30$

Table 9: Coal-Fueled Engine Capital Cost per 1.5 MW Engine ..................... 32

Table 10: Coal Engine Maintenance Cost ...................................................... 33

Table 11: Coal Engine Fuel Cost ................................................................. 34

Table 12: Coal Engine Capital and Operating Cost ........................................ $\quad 35$

Table 14: Oil-Fired Diesel Engine Capital Cost ............................................... $\quad 36$

Table 15: $\quad$ Oil-Fired Engine Maintenance Costs ................................................ $\quad 37$

Table 16: Oil-Fired Engine Capital and Operating Cost (in $\$ / \mathrm{kWh}$ ) ................ 38

Table 17: Annual Oil-Fired Diesel Engine Capital and Operating Cost (in \$/year) ......................................................................................... 38

Table 18: AMAX/ADL Cost Model Data (Assumed) ..................................... $\quad 40$

Table 19: AMAX/ADL Slurry Plant Model Coal and Slurry Plant .................. $\quad 40$

Table 20: Mine-Haul Truck Parametric Runs - Partial List .............................. 41

Table 21: Inland Waterway Tow Boat Parametric Runs - Partial List ............... 41

Table 22: Coal Cleaning Cost Effects on Annual Savings for Mine-Haul Truck ......................................................................................... 43

Table 23: Nozzle Life Cost Effects on Annual Savings for Mine-Haul Truck

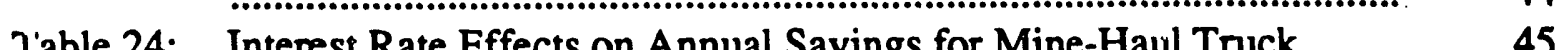

Table 25: Coal Cleaning Cost Effects on Annual Savings for Inland Tow Boat ............................................................................................. 46

Table 26: Nozzle Life Cost Effects on Annual Savings for Inland Tow Boat .. 47

Table 27: Interest Rate Effects on Annual Savings for Inland Tow Boat ......... 48

Table 28: Diesel Fuel Use Effects on Annual Savings for Mine-Haul Truck ... $\quad 49$

Table 29: Diesel Fuel Use Effects on Annual Savings for Inland Tow Boat ...... $\quad 50$ 


\section{Executive Summary}

The objective of Task 2 - Market Assessment and Economic Analysis - was to identify the market potential and economic feasibility of the future Detroit Diesel Corporation (DDC) coal-fueled, high-speed diesel engine. The results of this task were used to determine which specific heavy duty DDC engine and what market applications are most attractive for coal fuel. Task 2 results were also used to establish basic economic targets for the engine to be competitive, such as:

- Source coal price and location

- Coal cleaning cost, given assumed coal slurry specifications

- Engine parts cost increase to permit operation with coal fuel

- Load factor (equivalent full load hours per year)

- Maintenance and operating costs

- Emission control system capital and operating costs and size

- Diesel fuel costs at which the coal-fueled engine is cost competitive

Several applications for heavy duty diesels in the $400-2,500 \mathrm{hp}$ output class were surveyed, including off-highway mine-haul trucks, construction and industrial, marine and generator set applications. A set of "attractiveness criteria" for coal fuel operation was developed, and applied to screen the full range of engine application.

This preliminary screening resulted in two applications which appeared particularly well suited for coal fuel:

- Mine-haul truck engines. Equipped with 16V-149TI DDC engines, these 170-240 ton trucks operate in overburden and open pit mines including iron ore, copper, and coal. The total market is about $600-1,000$ truck engines per year in the U.S. and DDC has over $50 \%$ share.

- Barge, tug and work boat engines in the marine inland waterway sector. Most of the existing 4000 engines are naturally aspirated, $800-2,000 \mathrm{hp}$, and have relatively long service lives. DDC has a significant market share, and the DDC-149 coal slurry engine would be retrofittable to over $60 \%$ of the 5 million horsepower (hp) fleet.

Based on the results of this market assessment, DDC recommends that the Series 149 engine should be adopted for operation on CWS fuel at high speeds for the mine-haul off-highway truck and work boat marine markets. The DDC 149 diesel engine has a major share of these markets. Some of the economic and technical merits of a coal-fueled 149 engine are as follows:

- Series 149 engines use a relatively large amount of fuel per year. For a mine-haul off-highway truck ( $>170$ tons), 16V-149TI engines are used with 1,800 to $2,200 \mathrm{hp}$ rated power. The average load factor for a typical mine-haul truck is about $35 \%$, and it operates 5,000 to 7,000 hours per year. In case of a work boat engine, the load factor is greater than $50 \%$, and there are 5,000 to 8,000 operating hours per year. 
- An increase in the engine cost due to the coal fuel injection system, wear-resistant components, and emission control system should be tolerable on a Series 149 engine. In contrast, the cost of an on-highway coal-fueled engine would be expected to increase by an unacceptable amount compared to the price for the basic diesel engine.

- The 149 engine is a high-speed heavy-duty diesel engine with a large market share of the off-highway truck, industrial and marine applications. Therefore, once developed for tow boat and/or mine-haul truck application, a coal-fueled version of the engine could be adapted to many other possible applications.

- A large off-highway engine, like the Series 149 engine, will be better suited to accept the additional space and weight requirements of the emission control system posed by the use of coal fuels. Also, emission regulations for off-highway are not expected to be as stringent as for on-highway engines because off-highway trucks, industrial engines and marine vessels normally operate in remote areas far from the population centers.

Next, more detailed information for these two selected market applications was prepared to better assess their feasibility and relative merit. This information included DDC market share, duty cycle for engine operation, historical annual sales, emission control requirements, and specific geographical locations for the engines now in use (which enabled us to select suitable coal mines nearby). A detailed economic feasibility analysis was then performed using a spreadsheet model for life-cycle engine and fuel costs. Parametric studies were performed to explore the relative impact of various economic assumptions such as:

- Clean coal fuel cost relative to diesel fuel

- Engine efficiency

- Amount of diesel pilot fuel

- Load factor

The feasibility analysis predicted that the future use of coal fuel in the mine-haul truck and tow boat applications is feasible and has the potential to offer significant annual savings of up to $\$ 100,000$ per year for each vehicle. With an improvement in the cost of CWS fuel and wear-resistant engine components required for coal fuel operation, these savings are expected to increase. However, the future diesel fuel price will be critical in determining these savings. It was predicted that the inland tow boat application has potential for greater cost savings than the mine-haul truck. This because of higher load factor and lower CWS fuel cost for the towboat engines. The nationwide potential for displacing fuel oil with coal through widespread use of the DDC coal diesel engine is also greater for the towboat application.

Other conclusions are that nozzle life is relatively unimportant, and that 5 to $10 \%$ diesel fuel can be utilized for pilot and/or idle without upsetting the basic economic advantage. However, both engine load factor and engine efficiency are critical. 


\subsection{Objectives and Approach}

Based on the preliminary coal engine design developed by DDC, with inputs from SWRI and ADL, this task was conducted to identify the best opportunity(s) for DDC to enter the market with the future coal-fueled, high-speed diesel engine. The results of this market and economic feasibility assessment will be used to determine what specific heavy duty engine application(s) are most attractive for coal fuel, and also define basic economic targets for the engine to be competitive, such as:

- Source coal location and price

- Coal cleaning cost increment

- Engine parts cost associated with coal operation

- Hours per year of operation (equivalent full load)

- Maintenance and parts replacement costs

- Emission control system cost and size

- Diesel fuel costs at which DDC coal engine is cost competitive (lifecycle basis)

Our approach was to first survey all U.S. applications for heavy duty diesels in the $300-2,500 \mathrm{~kW}$ output class, including highway, generator set, marine, off-highway construction, and mining. A set of "attractiveness criteria" for coal fuel operation were developed, and applied to screen the full range of engine application. This preliminary screening resulted in two applications which appeared particularly well suited for coal fuel:

- Mine-haul truck engines

- Tow boat propulsion (inland waterways)

Our next task was develop more detailed information for each of these two selected market applications in order to better assess their feasibility and relative merit. This information included DDC market share, duty cycle for engine operation, historical annual shipments, emission control requirements, and specific geographical locations for the engines now in use (which enabled us to select suitable coal mines nearby).

A detailed economic feasibility analysis was then performed using a spreadsheet model for lifecycle engine and fuel costs. Parametric studies were performed to explore the relative impact of various economic assumptions such as:

- Clean coal fuel cost relative to diesel fuel

- Engine efficiency

- Amount of diesel pilot fuel

- Annual hours of operation

This feasibility analysis allowed us to identify the most promising applications and the cost and performance targets for entering this engine market. 


\subsection{Selectlon of Engline Applications}

\subsection{Candidate 300-2500 hp Engine Applications}

Heavy duty diesel engines in the 1,700-2,300 rpm rated speed class are widely recognized for their use in highway trucks and buses, where they account for approximately $6 \%$ of U.S. fuel oil usage. However, there are other applications for heavy duty diesels which are perhaps less widely known, but which may be more suitable for adaption to coal-water slurry fuel, such as:

- Off-highway, including mine-haul trucks

- Marine propulsion, including inland waterway vessels

- Generator sets and industrial drives

Detroit Diesel enjoys a significant market share in all of these applications and engine "market segments."

\subsection{Selectlon Criteria for Coal Fuel Feasibility}

Previous work on clean coal fuels for reciprocating engines has shown that the emission control requirements and the total annual fuel usage per engine are two factors of primary importance for economic feasibility. Annual fuel usage is critical because the benefit for the engine operator will be low coal fuel price compared to diesel fuel oil. In brief, the engine must burn enough coal fuel each year to pay for the extra cost of emission control (which is technically feasible, but relatively expensive on a \$/engine basis). For example, an application with $1,500-2,000 \mathrm{hp}$ engines operating 2,000 to 4,000 full-load equivalent hours/year and moderate emission control requirements will be preferred to a 500-1,000 hp engine application with only 1,500 full-load equivalent hrs/year and stringent emission controls. This is why the highway truck application is not attractive for coal fuel.

And the engine application must not be so rare that there are not enough engiries operating in a given region to justify a coal-cleaning plant (here the threshold level is about $500,000 \mathrm{hp}$, or 250 engines in the $2,000 \mathrm{hp}$ class). Preferably, those regions with large concentrations of engines will be in close proximity to "engine-grade" source coals (that is, source coals which can be economically cleaned to about $2 \%$ ash or better).

Also, the future potential displacement of oil by coal must be sufficient to justify the DDC coal engine development, and this implies that the total U.S. installed horsepower must be significant. For example, an engine application with an installed base of 4 million hp in the U.S. will account for 0.1 quad/year $\left(10^{14} \mathrm{Btu} / \mathrm{year}\right)$ of fuel usage, assuming 3,000 full-load hours and $8,000 \mathrm{Btu} / \mathrm{hp}-\mathrm{hr}$ heat rate. This is about $3 \%$ of total U.S. oil consumption (6\% of oil imports) which is quite significant.

Another factor favoring large engines is the cost of special hardware to burn coal fuels. This may include the injection system, costly wear-resistant parts for the injector tips, the piston rings and liners, the turbocharger, and the valves. This special hardware is 
expected to cost $\$ 30,000$ to $\$ 100,000$ per engine (dependent on engine size), which is tolerable for 1,500-2,000 hp engines but may exceed the engine cost itself for engines of about $500 \mathrm{hp}$.

Past work on coal diesel development also has shown that coal fuel operation favors steady running of the engine with minimum load and speed changes. Cold starts should also be kept to a minimum. Therefore, applications are favored which offer large blocks of time at steady load and speed, such as the marine propulsion application.

\subsection{Screening of Engine Applications}

Table 1 lists the evaluation criteria discussed above in Section 2.2, and shows how four candidate diesel engine applications were evaluated. A simple numerical rating system was used, and the outcome was so definitive that it was unnecessary to develop a more sophisticated evaluation method. The marine and mine haul applications received scores of +14 and +12 , respectively (far above the other two candidates).

The gen set and bus/truck applications did not score well in economic feasibility, largely because of (a) the relatively small engine size and fuel usage per engine, and (b) the relatively stringent emission control requirements. In many U.S. locations, there is pressure to replace industrial drives with electric motors because of emission regulations. The bus/truck application, although attractive for its large national fuel usage, also suffers from a non-steady duty cycle and the need to have a clean coal fuel infrastructure throughout the highway system.

As a result of this screening, the marine and mine-haul truck engine applications were selected as quite attractive for adaptation to clean coal slurry fuel.

These applications are examined in more detail in the following two sections. 


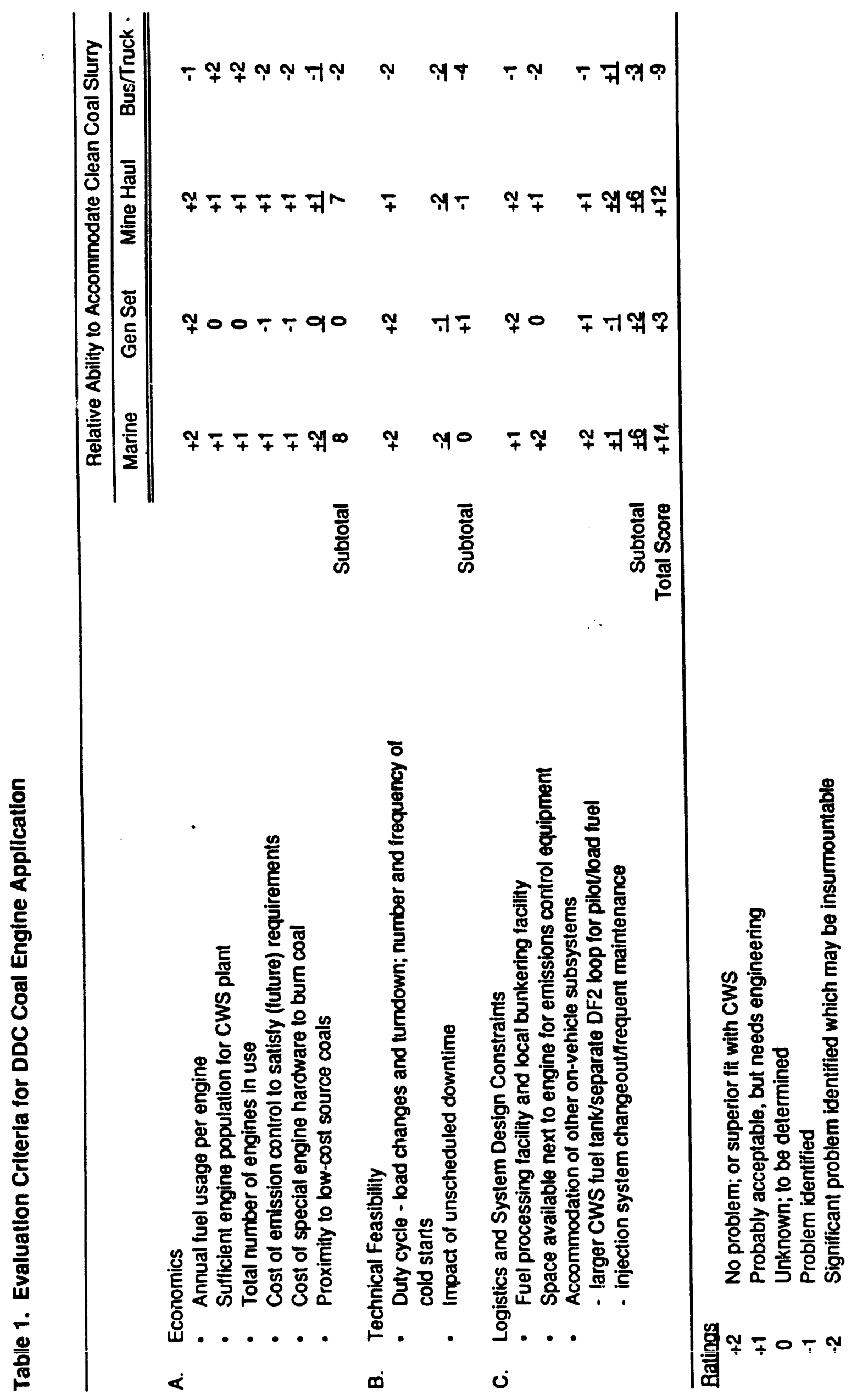




\subsection{Mine-Haul Truck Application}

\subsection{Description of Mine-Haul Truck (170-240 ton)}

Mine-haul trucks in the 170-240 ton class are the largest trucks produced and are about $20 \mathrm{ft}$. tall, 40-50 ft. long, with tires standing over $10 \mathrm{ft}$. tall. Empty, the vehicle weighs up to $350,000 \mathrm{lbs}$. These trucks are used in open-pit mines to transport overburden and coal (or ore) out of the mine pit. Figures 1,2,3, and 4 show typical trucks in use and representative dimensions, respectively.

Both electric drive models (diesel engines powering an alternator) and mechanical drive models (electronic transmission) are currently offered with key truck manufacturers including Marathon LeTourneau, WISEDA, VME-Americas, Unit Rig, and Dresser-Komatsu (Haulpak). The mine-haul truck is an ideal coal fuel application because engines are 1,500-2,000 hp and are used 16 to 24 hours per day with a high load duty cycle, as described below in Section 3.4. Detroit Diesel model 149 engines enjoy a significant market share in the U.S. (approximately 50\%), and also are exported to mines in South America, Australia, South Africa, China, and India. This opens up the possibility of export sales of clean coal technology. Three major types of surface mines use this class of trucks, as described below in Section 3.3:

- Surface coal mines (Western and Appalachian states)

- Iron-ore mines (Minnesota)

- Copper mines (Arizona, Utah, Nevada, and New Mexico)

The trucks cost about $\$ 1.5$ million new, with the engine itself account.ng for about $15 \%$ of the total cost.

\subsection{Schematic Design of Coal Engine System - Mine-Haul Truck}

The coal engine system would incorporate the sarne DDC 149 engine package (with special coal tolerant injection system, piston rings, etc.), but also include two new modules:

- Coal slurry fuel tank (1,200 gallons)

- Emission control system

The coal slurry fuel tank replaces one of the two 300-600 gallon diesel fuel tanks currently found on the truck on the underbody between the wheels. The emission control system is configured beside the cab under the overhand, so as to minimize interference to the vision of the operator. Figure 5 illustrates the schematic design. 

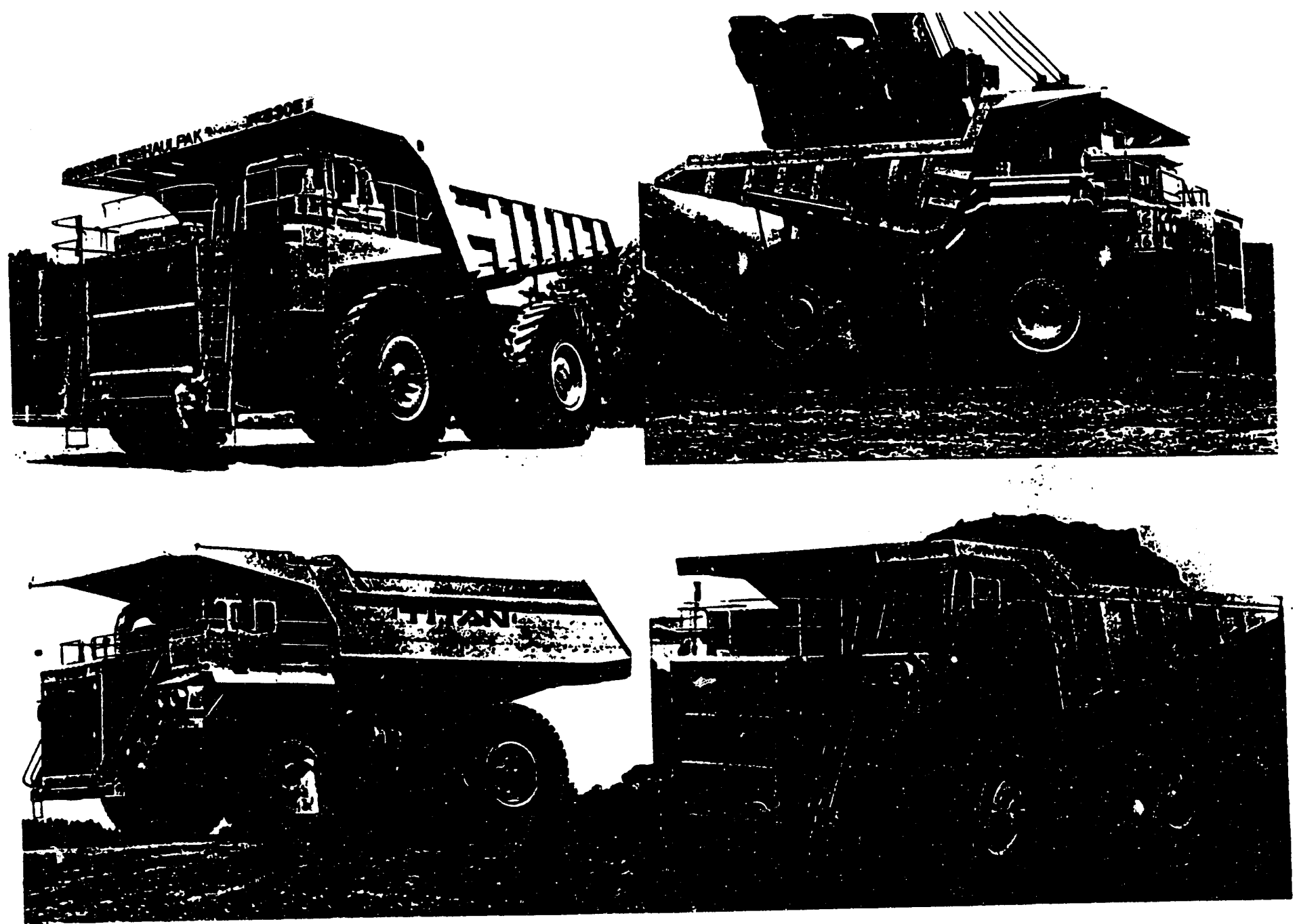

Figure 1. Typlcal Mine Haul Trucks In Operation 


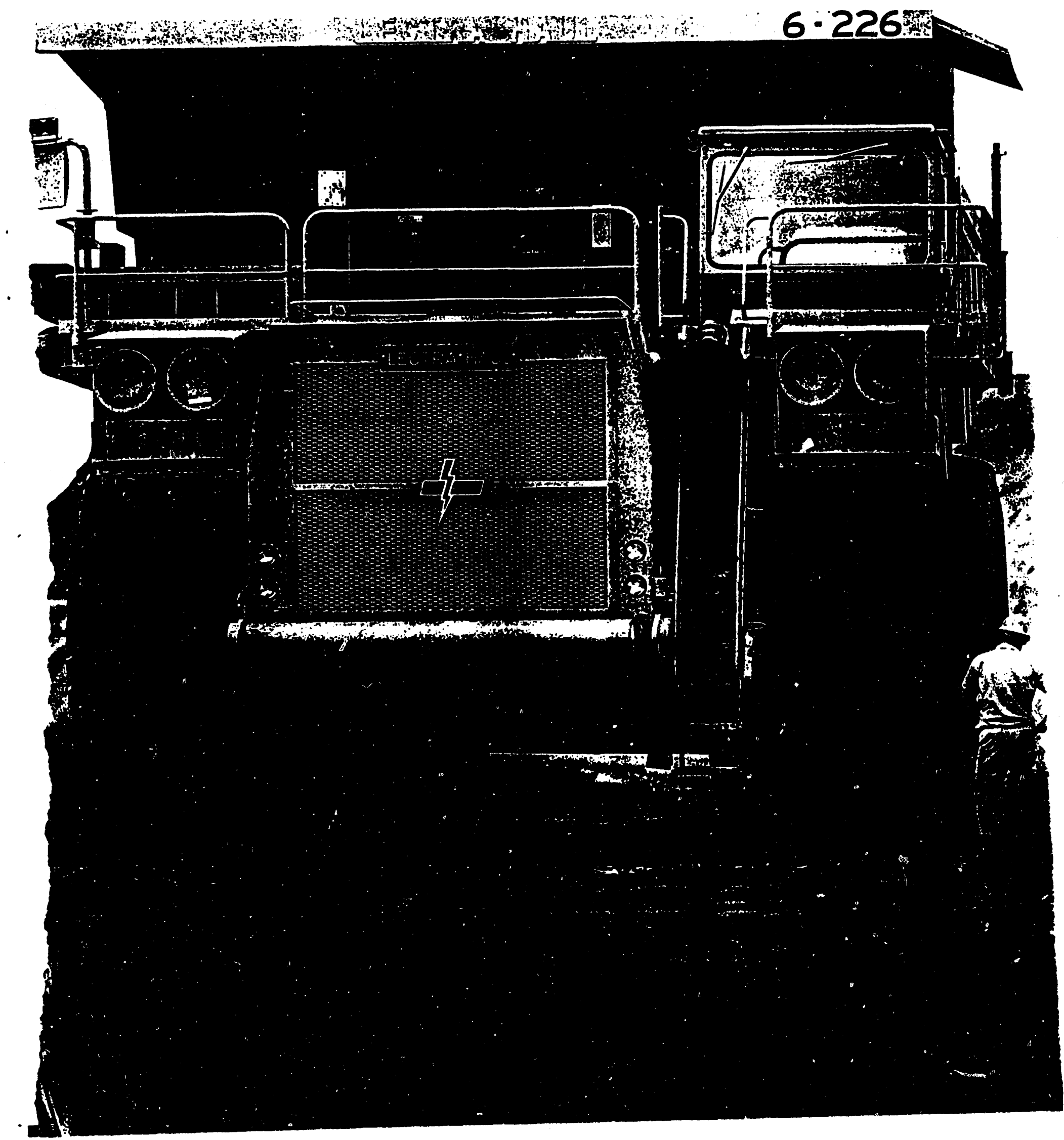

Figure 2. Mine Haul Truck (240-Ton Capacity) Showing Operators for Scale 


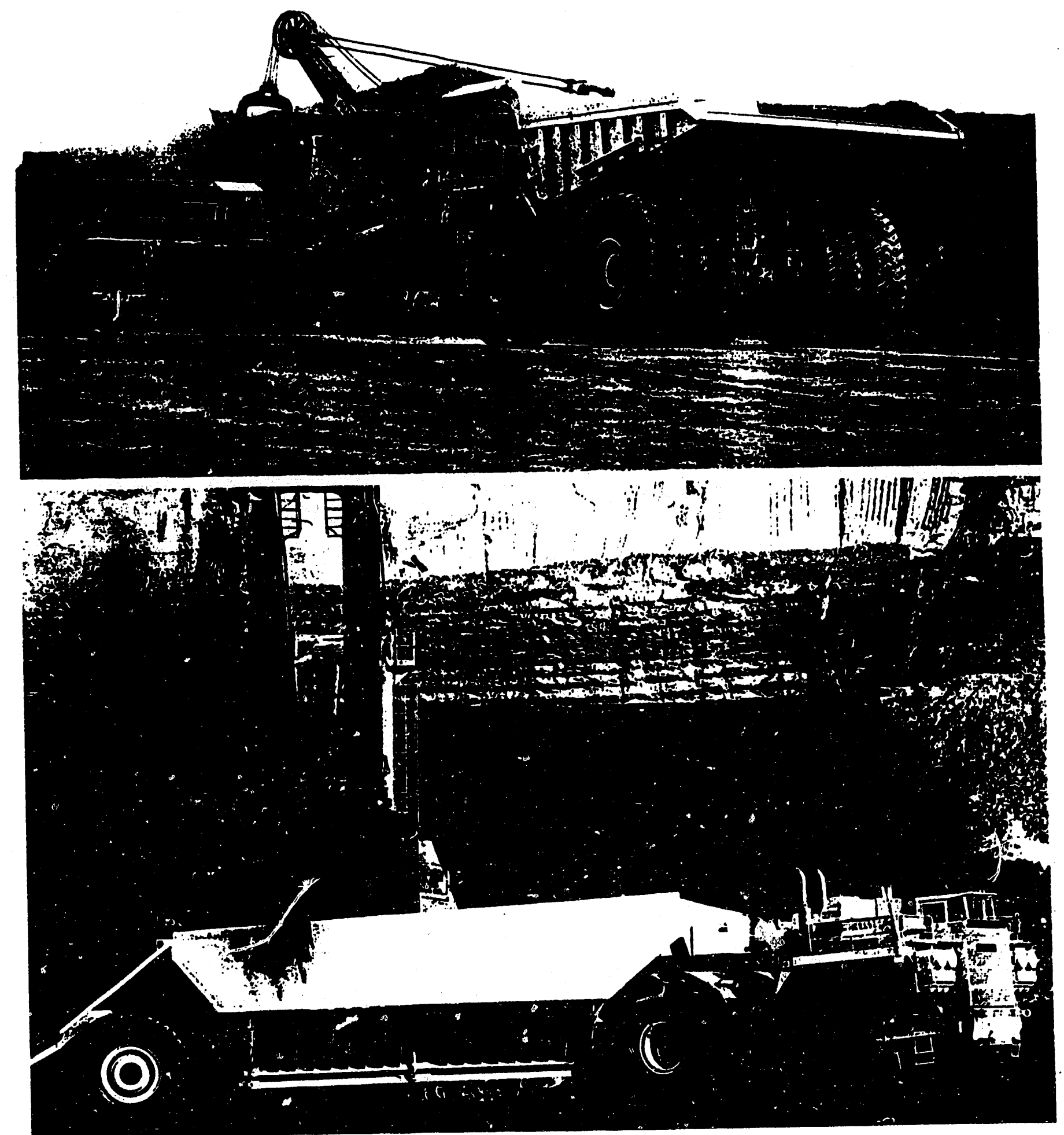

Figule 3. Mine Haul Trucks in Operation 


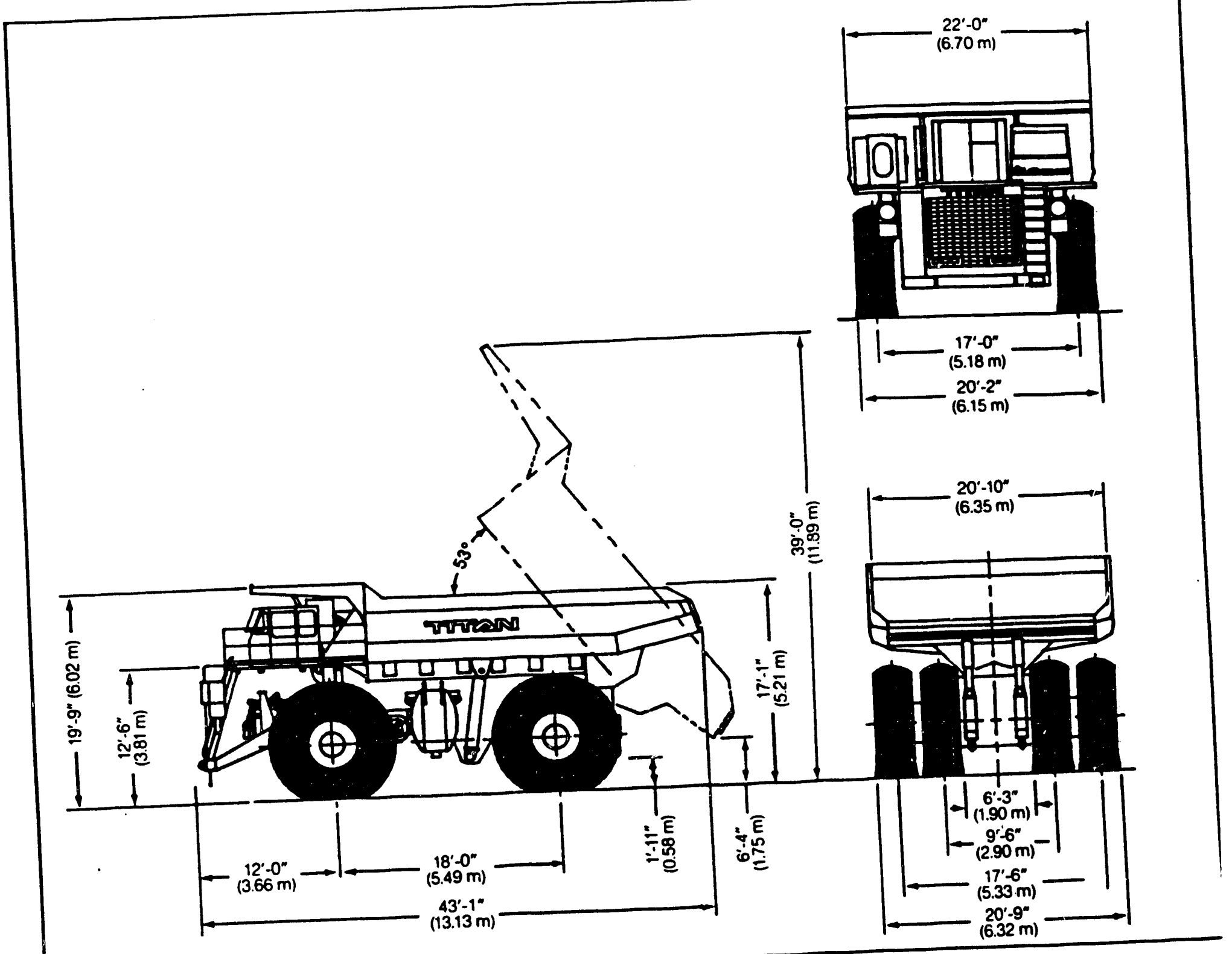

Figure 4. Major Dimensions of Typlcal Mine Haul Truck 


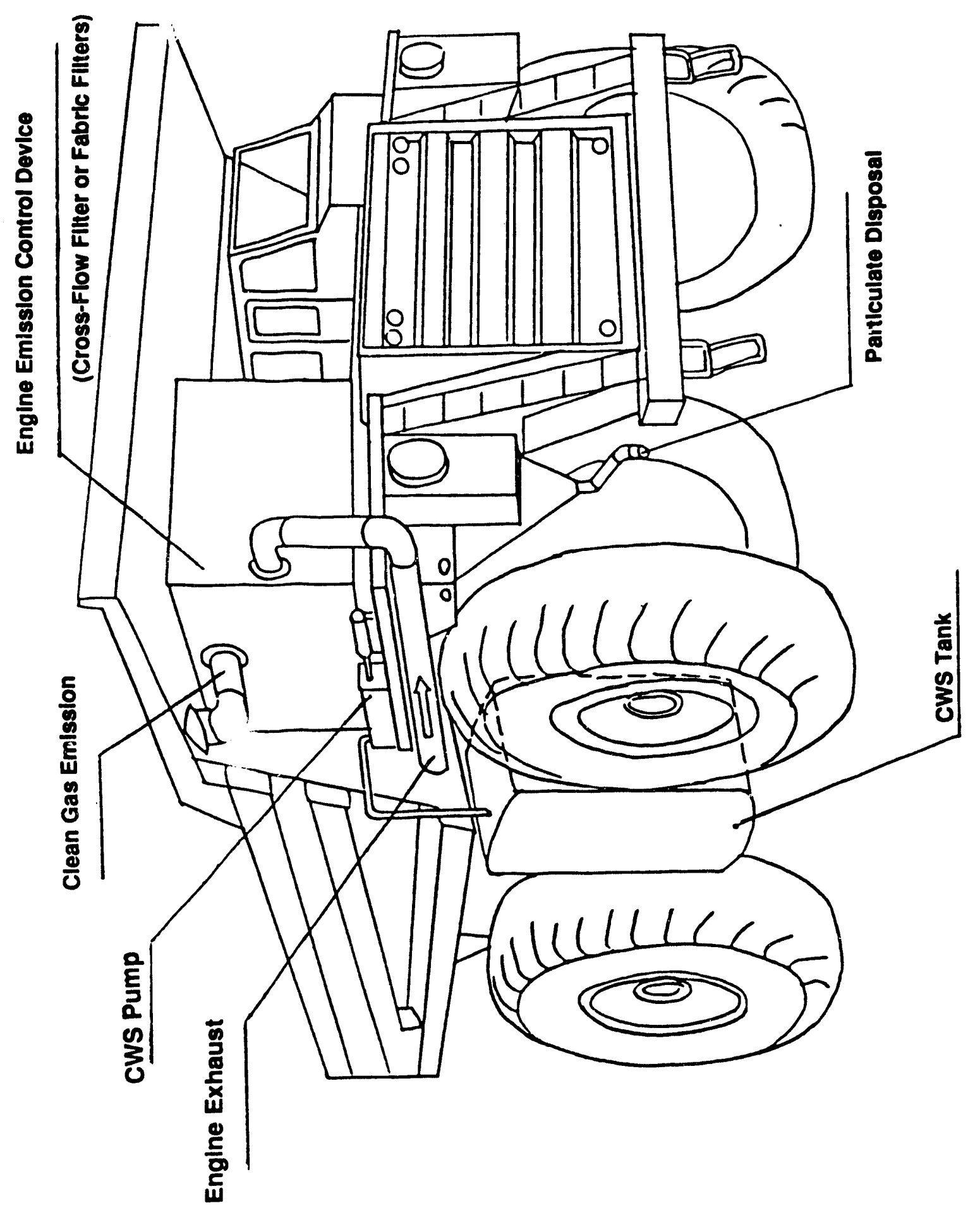

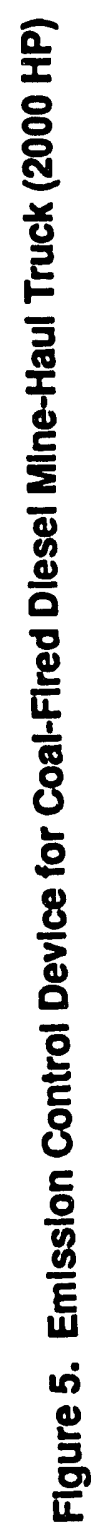




\subsection{Existing Mine-Haul Trucks - Population arid Sales by Mine Type}

The mine-haul truck market in the U.S. is in the range of 600-800 large mine-haul trucks per year, with $40 \%$ going to coal surface mines in ND, TX, WY, KY, and WV; $25 \%$ going to iron ore mines mainly in Minnesota; and 35\% going to copper mines in $\mathrm{AZ}, \mathrm{NM}, \mathrm{NV}$, and UT. There are an estimated 6,000-8,000 trucks in service with the average engine life about 50,000 operating hours (typical useful engine life is estimated to be 10 years at 5,000 hours per year). Figure 6 shows the U.S. mine-haul truck fleet regions of concentration by mine type.

Figure 6: Some Reglons with Large Fopulation of Mine-Haul Trucks

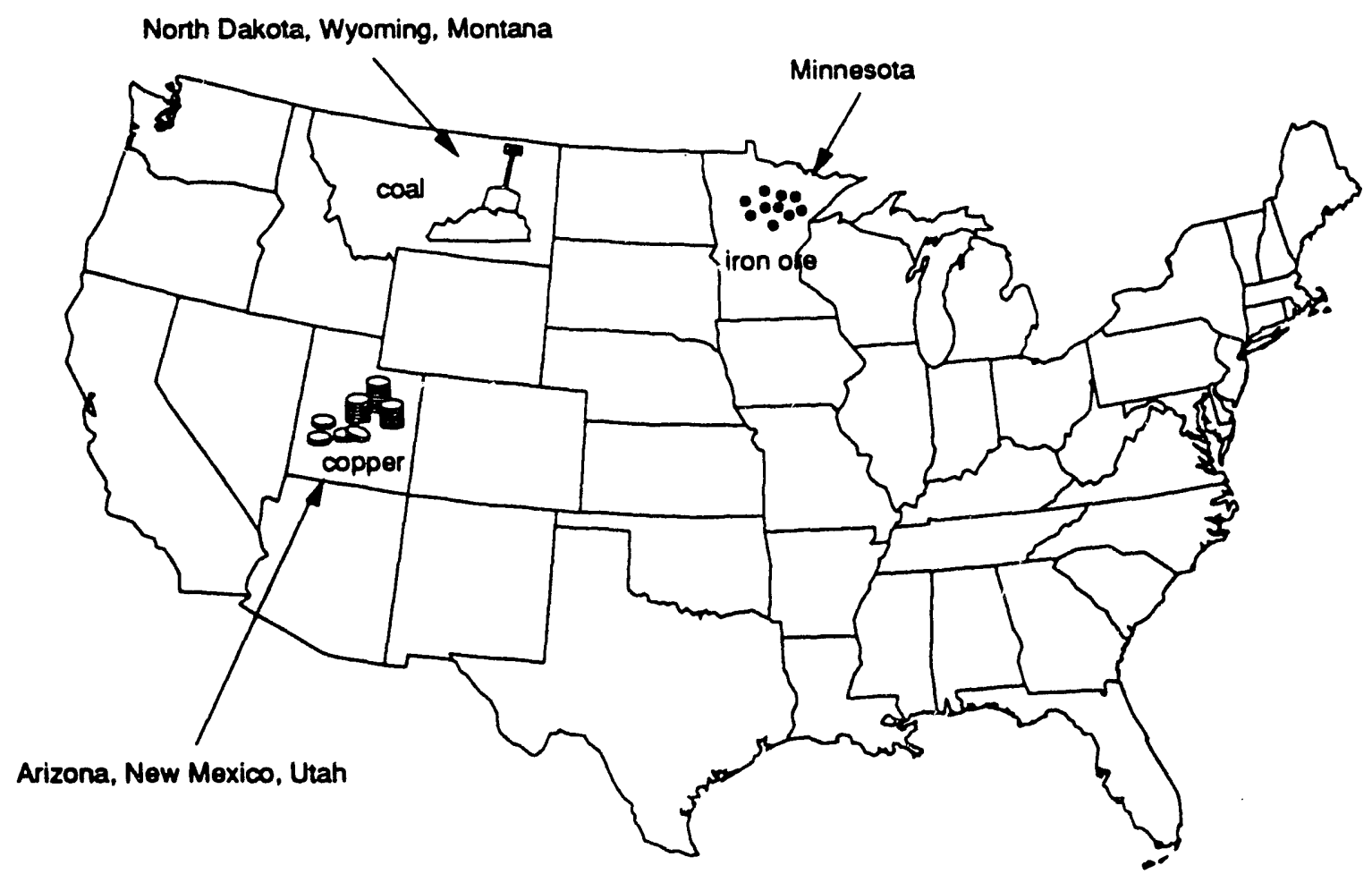

Table 2 shows the 15 leading copper mines in the U.S., showing that there is a concentration in Arizona, Utah, and New Mexico. The top 14 mines accounted for $95 \%$ of copper production in the U.S. Table 3 shows the top twenty major U.S. coal mines, including many surface mines in the Western region. These top twenty mines produced 260 million short tons in 1989, which is over half of the total 587 million short tons of surface mined coal in the U.S. that year (total coal mined 980 million, both surface and underground). This is to say that the mine-haul truck population is quite concentrated at perhaps 50 to 100 major sites in the U.S. In addition to this U.S. fleet, there is a vigorous export market of an estimated 1,000 mine-haul trucks per year to Chile, Australia, South Africa, China, India, and other countries. 
Table 2: Fifteen Leading Copper-Producing Mines in the Unlted States in 1989, In Order of Output

\begin{tabular}{|c|c|c|c|c|}
\hline Rank & Mine & County and State & Operator & $\begin{array}{l}\text { Capacity } \\
\text { (thousand } \\
\text { motrlc tons) }\end{array}$ \\
\hline $\begin{array}{r}1 \\
2 \\
3 \\
4 \\
5 \\
6 \\
7 \\
8 \\
9 \\
10 \\
11 \\
12 \\
13 \\
14 \\
15\end{array}$ & $\begin{array}{l}\text { Morenci } \\
\text { Bingham Canyon } \\
\text { Tyrone } \\
\text { Chino } \\
\text { San Manuel } \\
\text { Ray } \\
\text { Sierra } \\
\text { Bagdad } \\
\text { Pinto Valley } \\
\text { Inspiration } \\
\text { Mission Complex } \\
\text { White Pine } \\
\text { Continental } \\
\text { Troy } \\
\text { San Xavier }\end{array}$ & $\begin{array}{l}\text { Greenlee, AZ } \\
\text { Salt Lake, UT } \\
\text { Grant, NM } \\
\text { Grant, NM } \\
\text { Pinal, AZ } \\
\text { Pinal, AZ } \\
\text { Pima, AZ } \\
\text { Yavapai, AZ } \\
\text { Gila, AZ } \\
\text { Gila, AZ } \\
\text { Pima, AZ } \\
\text { Ontonagon, MI } \\
\text { Silver Bow, MT } \\
\text { Lincoln, MT } \\
\text { Pima, AZ }\end{array}$ & $\begin{array}{l}\text { Phelps Dodge Corp. } \\
\text { Kennecott, Utah Copper } \\
\text { Corp. } \\
\text { Phelps Dodge Corp. and } \\
\text { Burro Chief Copper Co. } \\
\text { Phelps Dodge Corp. } \\
\text { Magma Copper Co. } \\
\text { ASARCO Incorporated } \\
\text { Cyprus Sierrita Corp. } \\
\text { Cyprus Bagdad Copper Co. } \\
\text { Pinto Valley Copper Corp. } \\
\text { Cyprus Miami Mining Corp. } \\
\text { ASARCO Incorporated } \\
\text { Copper Range Co. } \\
\text { Montana Resources, Inc. } \\
\text { ASARCO Incorporated } \\
\text { ASARCO Incorporated }\end{array}$ & $\begin{array}{r}305 \\
245 \\
160 \\
150 \\
130 \\
125 \\
117 \\
97 \\
92 \\
65 \\
70 \\
50 \\
50 \\
18 \\
15\end{array}$ \\
\hline
\end{tabular}

Table 3: Major U.S. Coal Mines, 1989 (Million Short Tons)

\begin{tabular}{lllcl}
\hline \multicolumn{1}{c}{ Mine Name } & Type & Location & Tonnage & Company \\
\hline Black Thunder & Surtace & Wyo. & 29.6 & ARCO Coal \\
Jacobs Range & Surface & Wyo. & 14.7 & Kerr-McGee \\
Rosebud & Surface & Mont. & 13.7 & Western Energy \\
Belle Ayr & Surface & Wyo. & 13.7 & ARCO Coal \\
Eagle Butte & Surface & Wyo. & 13.6 & AMAX Coal \\
Cordero & Surface & Wyo. & 13.0 & Sun Coal \\
Caballo & Surface & Wyo. & 12.9 & Carter Mining \\
Martin Lake & Surface & Texas & 12.5 & Texas Utilities \\
Monticello & Surface & Texas & 11.8 & Texas Utilities \\
Freedom & Surface & N.D. & 11.5 & Coteau \\
Rochelle & Surface & Wyo. & 10.9 & Rochelle \\
Rawhide & Surface & Wyo. & 10.6 & Carter Mining \\
Decker & Surface & Mont. & 9.9 & Decker \\
Navajo & Surface & N.M. & 9.0 & BHP-Utah \\
Buckskin & Surface & Wyo. & 8.9 & Triton Coal \\
Cabalo Rojo & Surface & Wyo. & 8.3 & Mobil Coal \\
Jewett & Surface & Texas & 8.1 & North. Resources \\
Kayenta & Surface & Ariz. & 7.8 & Peabody \\
Falkirk & Surface & N.D. & 7.1 & Falkirk \\
North Antelope & Surface & Wyo. & 6.9 & North Antelope \\
\hline
\end{tabular}

Source: 1991 Keystone Coal Industry Manual

\subsection{Duty Cycle, Engine Efficiency and Overall Fuel Usage}

It is difficult to define a single typical mine-haul truck duty cycle because of the variety of mine layouts, shallow versus deep pits, length of truck travel to exit the pit, and grade 
(6-9\%) slope. However, the major fuel usage is during the uphill haul up the grade, which may vary from under one mile up to several miles. The sequence of operations in the duty cycle consists of five modes, as follows:

Mode 1 Loading under the mining shovels

$5 \pm$ minutes; engine at idle or low

Mode 2 Uphill haul

RPM; approximately $15 \%$ load

$10 \pm$ minutes; engine at near rated

Mode 3 Dump power (full speed, $100 \%$ load) $3 \pm$ minutes; engine at part load (approximately $20 \%$ load; $1,600-1,900 \mathrm{rpm})$

Mode 4 Downhill run

$7 \pm$ minutes; engine at low load (10-15\% torque)

Mode 5 Wait for shovel

$5 \pm$ minutes; engine at idle or low RPM

Full power fuel consumption of the DDC $16 \mathrm{~V}-149$-TI diesel engine at $2,000 \mathrm{hp}, 1,900$ rpm is 95 gallons per hour (1.57 gallons per minute). Therefore, for example, if the mine haul engine operates 10 minutes on uphill haul (mode 2), the fuel consumption during that time would be 15.7 gallons. Idle fuel consumption is 6 gallons pir hour.

Figures provided by several operators of large mine-haul truck fleets indicate 25-30 gallons per hour per truck is typical. Since the trucks make 1-2 round trips per hour, this confirms that the uphill haul accounts for most of the fuel usage. Engine efficiency over the duty cycle ranges from 32 to $37 \%$ on a higher heating value (HHV) basis, depending on the specific diesel engine model and how much part load and idle operation is involved. For example, the 149 engine has a peak efficiency of $38 \%$ (HHV) at full load and rated speed. For the purposes of the analysis in Sections 6 and 7, we have assumed a nominal efficiency of $34 \%$ (HHV) over the duty cycle. Additional runs were made at another engine efficiency level just to test sensitivity.

DDC provided field data for one specific mine-haul truck application which indicated that over the duty cycle the fuel consumption was about $.37 \mathrm{lb} / \mathrm{hp} \cdot \mathrm{hr}$. This corresponds to $6,800 \mathrm{Btu} / \mathrm{hp} \cdot \mathrm{hr}$ or $34.9 \% \mathrm{HHV}$, which supports the assumption of $34 \%$.

The larger mines operate a fleet of 15 to 30 active large trucks for 24 hours per day, with a budget of 2 to 5 million gallons of fuel per year. Fuel is typically $15-20 \%$ of total operating cost per ton in a 100,000 ton/day mine. The large fuel oil budget of each major mine operator means that penetration of this market segment by coal engines can be accomplished readily, provided the cost savings of coal diesel engine are demonstrated.

The overall fuel usage in the U.S. by this engine application can be estimated as follows. If 2,000 active trucks are assumed to use 25 gallons per hour for 4,000 hours per year, the total estimate is 200 million gallons per year $\left(0.03\right.$ quad or $0.3 \times 10^{14} \mathrm{Btu} /$ year $)$. Alternatively, if the total annual tonnage in surface mines (coal, ore, and overburden) is 
1000 million tons, and an average fuel use of 0.15 gallons per ton is assumed, one obtains 150 million gallons per year $\left(0.02\right.$ quad or $0.2 \times 10^{14} \mathrm{Btu} /$ year $)$. These estimates are reasonably consistent and give the total potential national impact of coal fuel substitution for the mine-haul truck market.

\subsection{Mine locations and Coal Slurry Logistics}

For the surface coal mines in the Powder River Basin, it is clear that the preferred source coal for a clean coal slurry powered truck fleet would be in that same region. It has been demonstrated that several coals in this region are indeed cleanable to engine grade quality. The AMAX/ADL coal cleaning plant model suggests a typical clean coal slurry price produced near the mine site in the Powder River Basin would be \$2.92/MMBt.u in 1991 dollars.

For the copper mines in Arizona and neighboring states, the western source coals are also most convenient, but there would be a transportation cost to the slurry plant, because this plant must be located 20-50 miles from the mine-haul truck fleets. For example, assuming a Salt Lake City slurry plant location, the AMAX/ADL coal cleaning plant model suggests a slurry price of $\$ 3.55 / \mathrm{MMB}$, including $\$ 0.55 / \mathrm{MMBtu}$ for transportation.

\subsection{Basellne Operating Costs/Engine Parts Replacement}

Based on DDC inputs, we assumed an average engine maintenance cost of $\$ 22,000$ per year for a 2,000 hp 16V-149 TI engine over the total life of the engine. This is based on diesel fuel oil operation excluding fuel cost, but includes engine parts replacement and maintenance according to the following assumed schedule:

- Oil, fuel filters, and air cleaner checked $250 \mathrm{hr}$

- Oil filter replaced, air cleaner cleaned $500 \mathrm{hr}$

- Replace air cleaner element $\quad 1,000 \mathrm{hr}$

- Fuel injectors replaced $\quad 5,000 \mathrm{hr}$

- Minor overhaul including rings, valves; $12,000 \mathrm{hr}$ check bearings

- Major overhaul $24,000 \mathrm{hr}$

- head replacement

- drivetrain gears

- crank reground

- Remanufacture engine including block $60,000 \mathrm{hr}$ replacement

Tires, hydraulics, transmission, and vehicle repairs are major costs not included in this figure because they would be common to both diesel oil operation and coal fuel operation. 


\subsection{Inland Waterway Towboat Application}

\subsection{Description of Towboat Application}

Inland waterway transport is a major U.S. mode of freight traffic consisting mainly of barges pushed or pulled by diesel powered tugs or towboats. Each boat typically moves 10 to 16 barges with the engine operating close to full load (for example, the DDC model 149 engine would operate at $1,440 \mathrm{hp}$ at $1,800 \mathrm{rpm}$ on the marine curve - see Figure 7). Figure 8 shows a typical inland waterway towboat in operation. Marine engines operate continuously 5,000-6,000 hours per year and are rated more conservatively than off-highway engines. They are potentially an excellent application for coal fuel because of steady load operation and high load factor.

\subsection{Schematic Design of Coal Engine System - Towboat}

Figure 9 shows how the coal slurry fuel tank and emission control system might be configured on a towboat. The engine package envelope itself would be essentially identical for diesel oil and coal fuel compared to the mine-haul truck application, there is a little more space typically available on towboats compared to mine-haul trucks, although there are obvious limitations on slurry tank size.

\subsection{Exlsting Towboat Engines - Population and Sales}

Based on data provided by Waterways Joumal, Arthur D. Little compiled an engine database of 3,700 work boats active on inland waterways in the U.S. The database shows vessel serial number, engine manufacturer and model, vessel horsepower, and year built. The results can be summarized as follows (see Table 4). The retrofit potential is noted in the last column, largely based on engine size. It is clear that of the 4.5 million horsepower presently installed, 50-75\% of towboat engines have the potential to be replaced by DDC 149 coal engines, when developed.

Sales of new vessels in the U.S. have not been brisk in the last several years; a total of 29 new inland waterway boats were built in the 1986-1990 period (this is less than $1 \%$ of the vessel population). Marine engine sales are much more active, with 50-100 DDC-149 engines sold per year. 


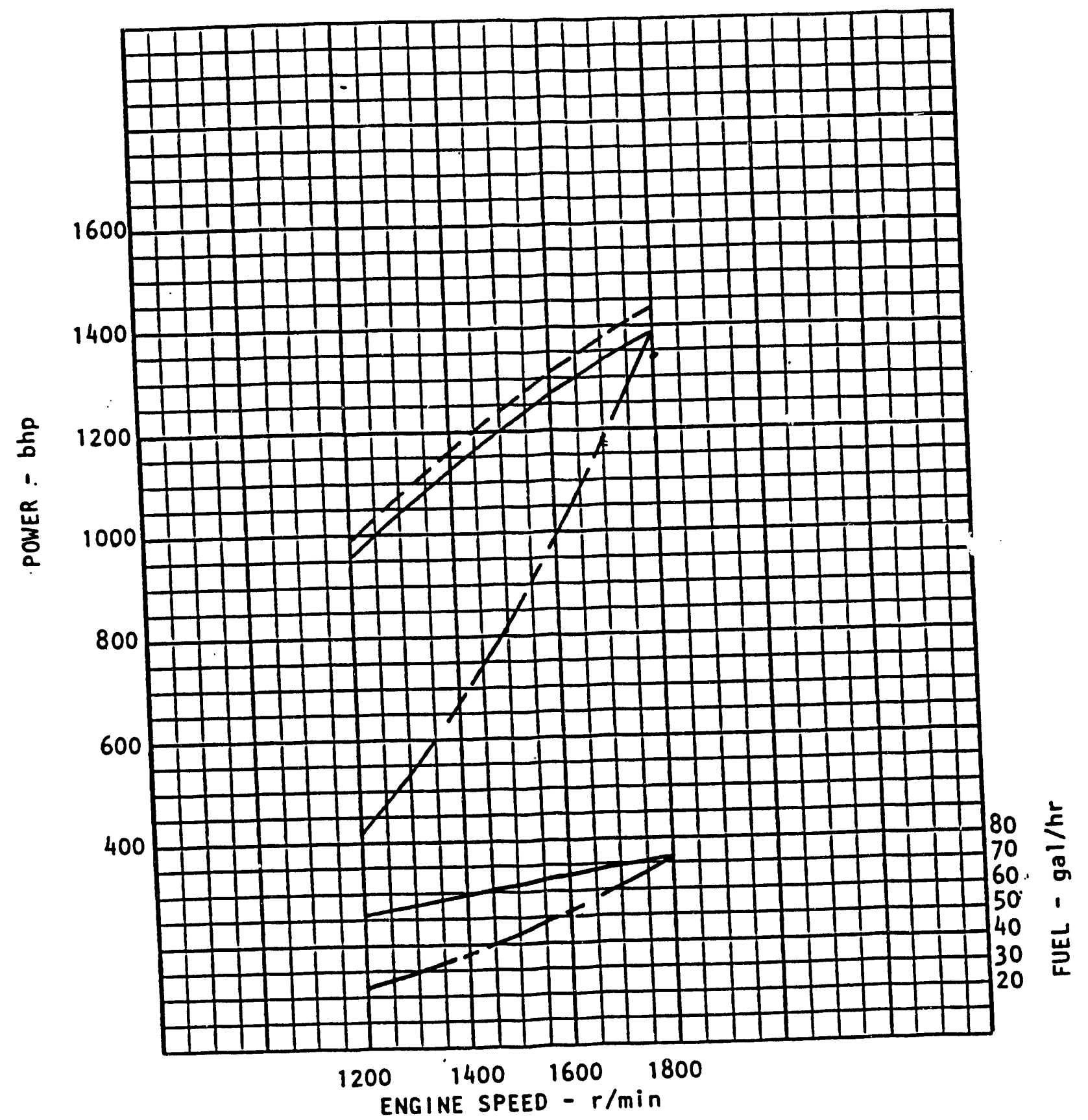

-...-

SHAFT HORSEPOWER

PROPELLER LOAD

Figure 7. Englne Performance Curve, DDC Model 16V-149T1 Marine-Continuous 


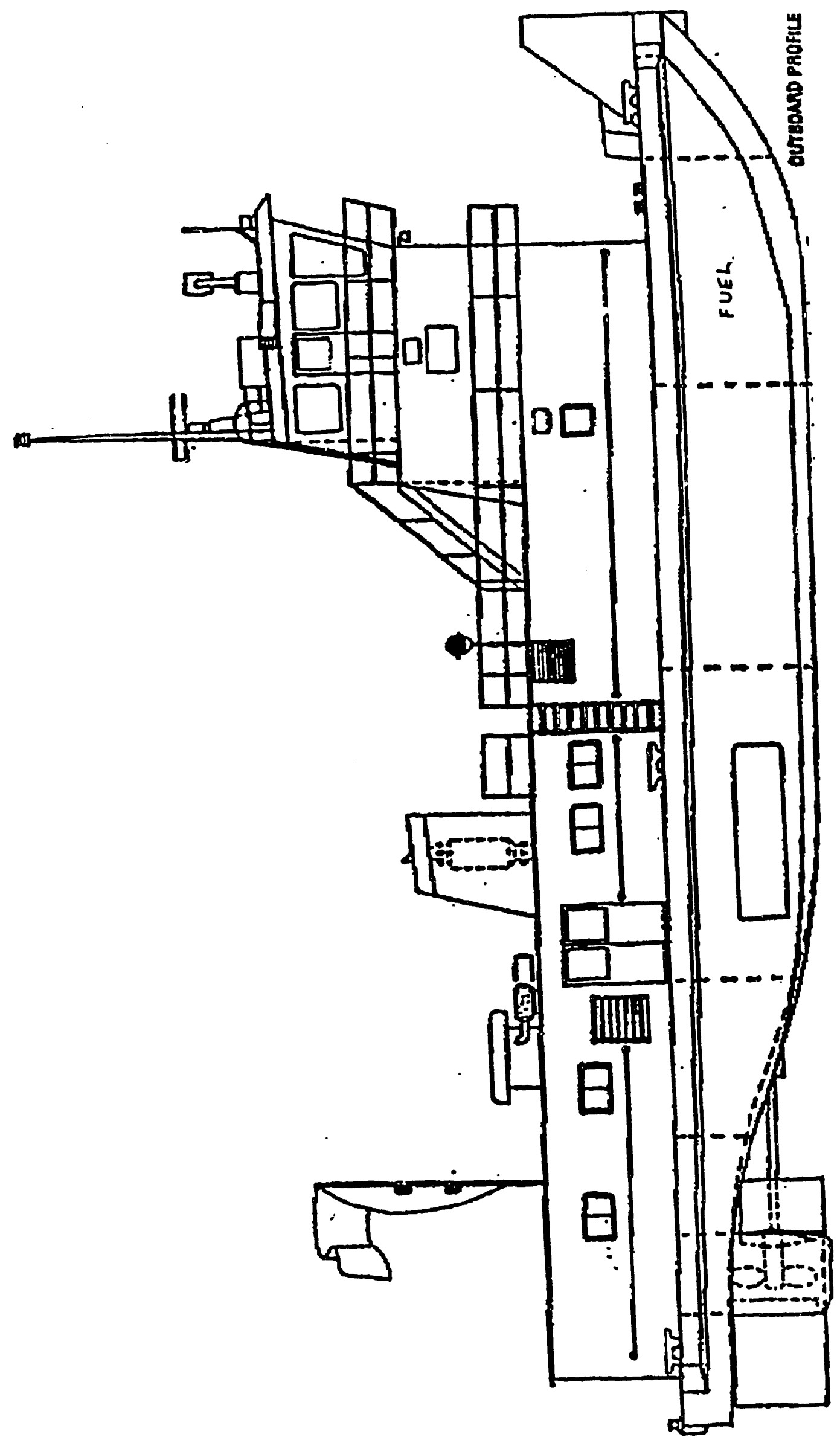

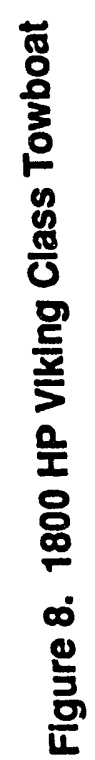




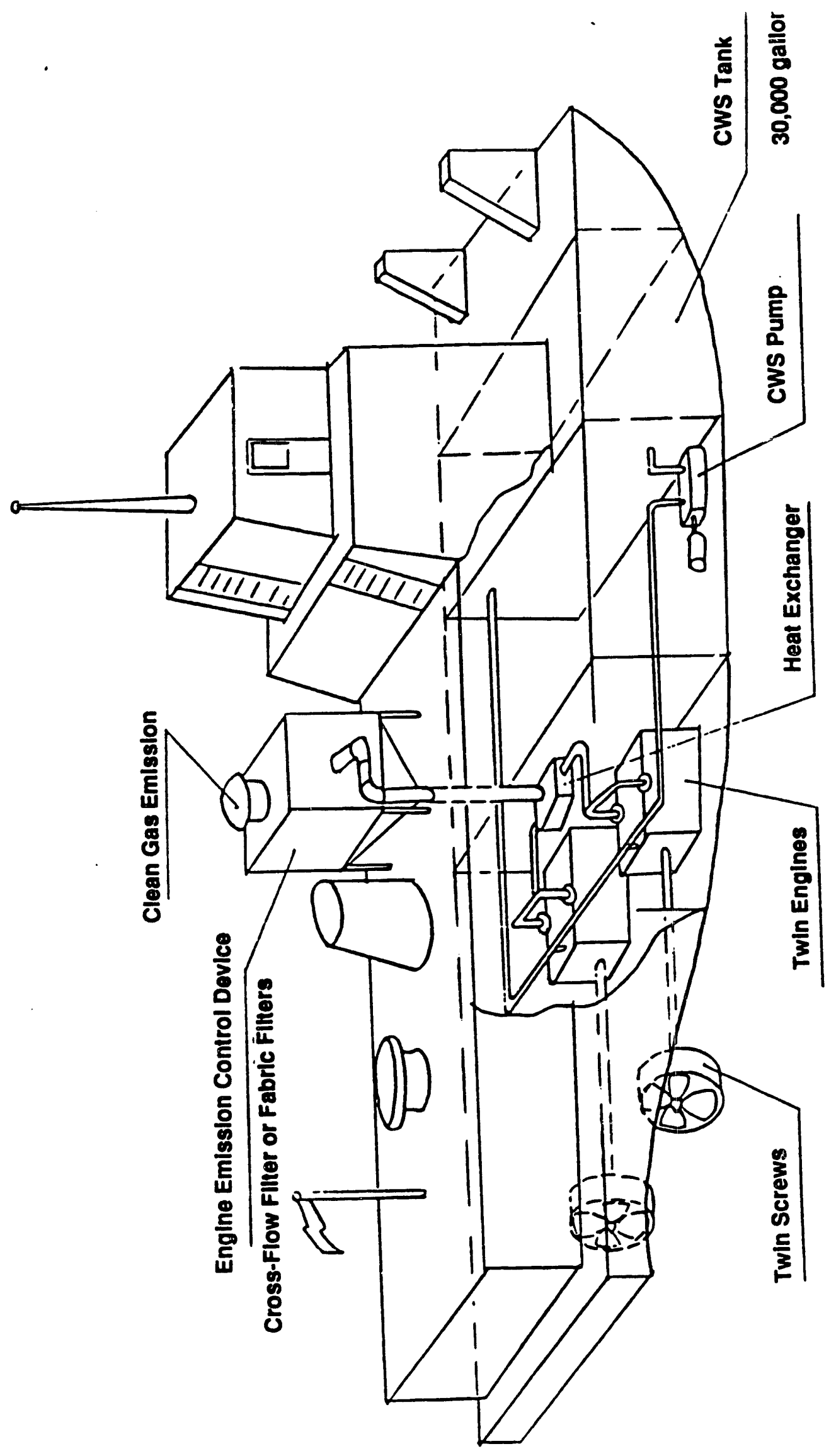

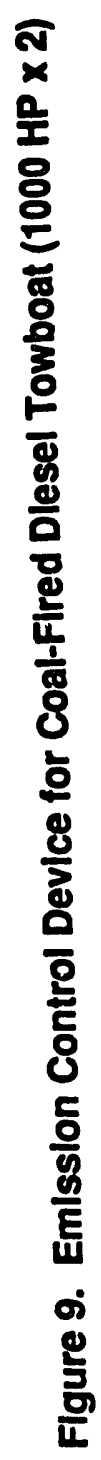


Table 4: Inland Waterway Towboat Engine Database Results

\begin{tabular}{|c|c|c|c|c|}
\hline Engine Model & $\begin{array}{c}\text { Typlcal Vessel } \\
\text { hp }\end{array}$ & $\begin{array}{c}\text { Number of } \\
\text { Vessols }\end{array}$ & $\begin{array}{r}\text { Total } \\
\text { Horsepower }\end{array}$ & $\begin{array}{l}\text { Retrofit Potontlal for } \\
\text { DDC } 149 \text { Coal Engine }\end{array}$ \\
\hline DDC Model 92 & 600 or 1,200 & 151 & 162,000 & Possible with 8V-149 \\
\hline DDC Model 149 & 1,350 or 1,800 & 190 & 287.000 & Excellent \\
\hline EMD Model 567 & 3,000 (avg) & 160 & 418,000 & Good \\
\hline Miscell GM & 2,000 (avg) & 42 & 79,000 & Good \\
\hline DDC Model V.71 & $500-1,000$ & 1340 & 851,000 & Poor \\
\hline $6-110$ & Approx 400 & 75 & 27,000 & Poor \\
\hline \multicolumn{5}{|l|}{ EMD Model 645} \\
\hline $12 \mathrm{cyl}$. & 2,800 or 4,300 & 124 & 444,000 & Excellent \\
\hline $16 \mathrm{cyl}$. & 3,400 to 9,000 & 244 & $1,210,00$ & Excellent \\
\hline $20 \mathrm{cyl}$. & 7,000 to 10,500 & 32 & 253,000 & Poor \\
\hline $8 \mathrm{cyl}$. & 1,800 or 3,000 & 28 & 70,000 & Good \\
\hline \multicolumn{5}{|l|}{ Other manufac. } \\
\hline \multirow[t]{2}{*}{$\begin{array}{l}\text { Cummins, } \\
\text { Caterpiller, Alco }\end{array}$} & varies: $500-4,000$ & 1,303 & $1,646,000$ & Good for certain engines \\
\hline & Totals & 3,690 & $4,454,000$ & \\
\hline
\end{tabular}

Source: Inland River Record, 1991

\subsection{Duty Cycle and Overall Fuel Usage}

The actual engine operating data was obtained from a 1988 study of a towboat equipped with two 12V-149NA engines (675 hp each). These engines were naturally aspirated and this is not unusual for towboats. The data revealed that for the period that the engines were on, the towboat operated $67 \%$ of the time with both engines at about $90 \%$ load $(1800 \pm 20 \mathrm{rpm}, 620 \mathrm{hp}, 35-40$ gallons per hour each). Figure 10 shows a typical distribution of operating time for the port and starboard engines; some $20 \%$ of each engine's operating time was spent at idle or below $1000 \mathrm{rpm}$, where the fuel consumption is about 5 gallons per hour. The average engine fuel consumption during this test was approximately 29 gallons per hour $(.35 \mathrm{lb} / \mathrm{hp}$-hr or $.051 \mathrm{gallon} / \mathrm{hp}-\mathrm{hr})$. This is equivalent to an engine efficiency of approximately $36.5 \%$ (HHV).

Data provided by two leading towboat fleet operators were very consistent in total fuel usage per year per horsepower:

Operator A: $\quad 86$ active boats $\quad 374,000 \mathrm{hp} \quad 61 \pm 1$ million gallons

Operator B: $\quad 100$ active boats $\quad 367,000 \mathrm{hp} \quad 60$ million gallons




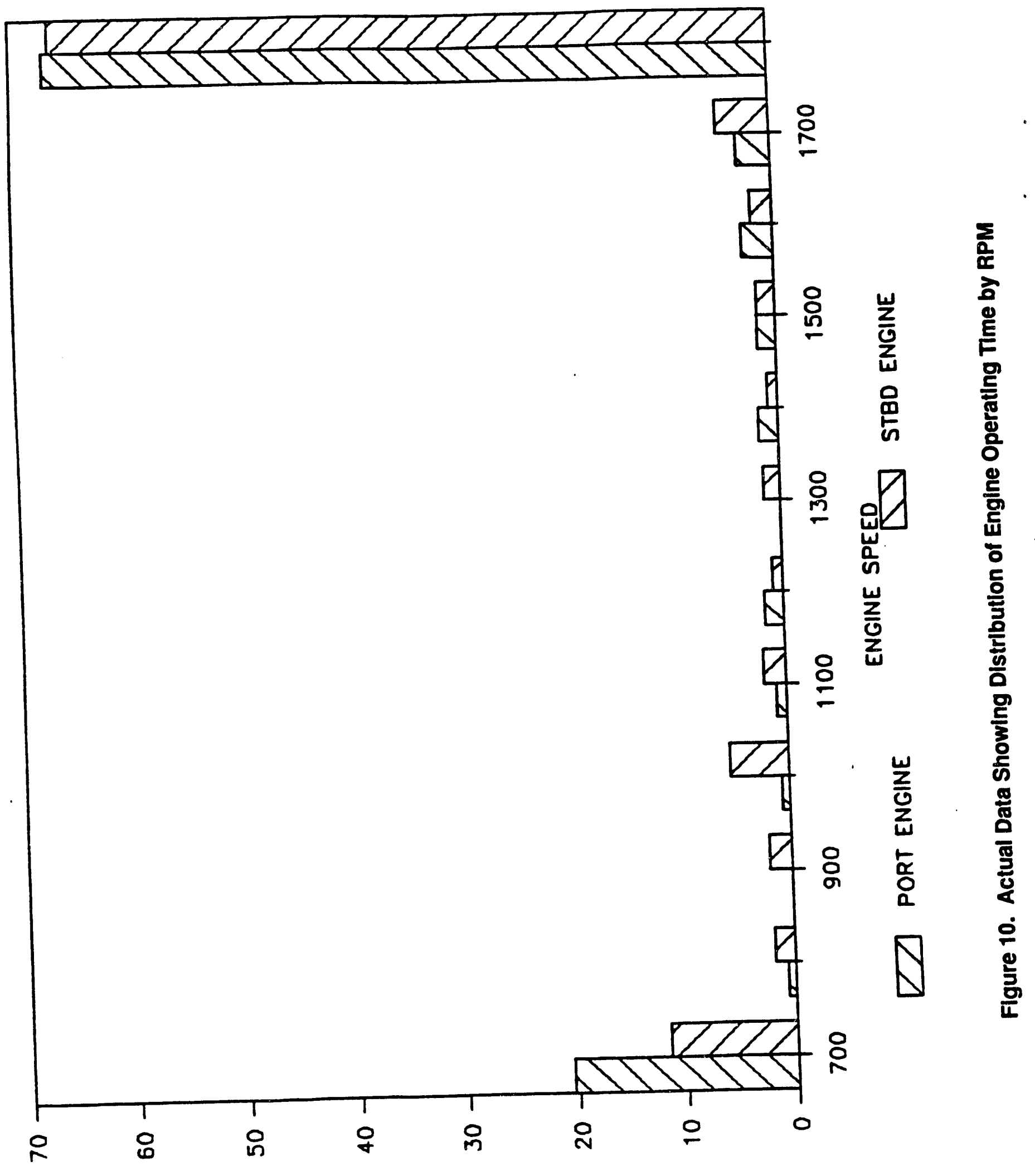

$\exists W I \perp$ ONILYZJdO JO LNJJYId 
These two operators alone account for $16 \%$ of the total engine hp in service in the U.S. From this limited data we can arrive at an average figure of 163 gallons per hp-year. The average $3,700-4,300 \mathrm{hp}$ per vessel for these two operators would indicate that the engines were EMD model $645 \mathrm{~s}$. The large fuel usage by towboat fleet operators would facilitate the market penetration of the coal fuel engine once cost savings can be demonstrated.

Combining the duty cycle data with the operator fuel use data, we can estimate that active towboat engines operate an average of 3,200 \pm 300 hours per year. This is about a $40 \%$ overall load factor on an annual basis. The average specific fuel consumption over the duty cycle was assumed to be .05 gallon/hp- $\mathrm{hr}$ in agreement with the operating data.

This agrees with DOE/EIA statistics. The total U.S. fuel usage for this engine application can be estimated at 765 million gallons per year $\left(1.1 \times 10^{14}\right.$ Btu or 0.11 quad). This is about three times the fuel usage by the mine haul sector. DOE/EIA statistics (Petroleum Marketing Annual, 1988) show distillate fuel oil vessel bunkering averaged 765 million gallons for 1987 and 1988, distributed as follows:

- Kentucky 85 million

- Missouri 44 million

- Tennessee 91 million

- Louisiana 460 million

- Mississippi 85 million

This excludes Florida, Alabama, and Texas, which together account for an additional 500 million gallons per year, much of which is used for coastal and Gulf of Mexico activities.

\subsection{Towboat Operating Routes and Coal Slurry Logistics}

The majority of inland waterway activity is along the Mississippi River and its tributaries, as noted by the fuel usage statistics cited above. Towboats typically carry 20,000 gallons of fuel oil which can allow them to operate up to 700 hours (four weeks) without refueling.

Source coals which are readily cleanable are available from mines which are in close proximity to the Mississippi River waterway system (e.g., Kentucky, West Virginia, Virginia, Ohio, Missouri, Pennsylvania, Illinois). The slurry plant serving a towboat fleet is most logically placed at an existing bunkering terminal, with coal transported at low cost by barge to the slurry plant. This system of coal fuel logistics lends to a relatively low cost engine-grade slurry. For example, if Pittsburgh is selected as a slurry plant site and a $1-2 \%$ ash specification is assumed, the coal fuel price would be $\$ 3.00 / \mathrm{MMBtu}$, according to the AMAX/ADL coal cleaning model. 


\subsection{Baseline Operating Costs/Engine Parts Replacement}

The engine maintenance costs (excluding fuel) are essentially equivalent to the mine haul application (approximately $\$ 10$ per hp per year). For details on engine parts replacement see Section 3.6 above.

The towboat fleet operator would benefit from the future coal-fuel price advantage because fuel is a large percentage of total operating cost, compared to $18 \%$ of operating cost for mine-haul trucks. Also, the larger fleet operators are faced with annual fuel bills of about 60 million gallons, compared to the $2-5$ million gallon annual fuel bill of a large surface mine. 


\subsection{Emission Control System for Mine-Haul Truck and Towboat Englnes}

Emissions control options were considered and preliminary design sketches prepared as a basis for the economic analysis. The design criteria assumed were as follows (see Table 5):

Tabie 5: Emission Control System Design Ascumptions

\begin{tabular}{|c|c|}
\hline \multicolumn{2}{|l|}{ Performance } \\
\hline $\mathrm{SO}_{2}$ & $\begin{array}{l}50-70 \% \text { reduction (depending on fuel } \\
\text { sulfur) }\end{array}$ \\
\hline $\mathrm{NO}_{x}$ & $\begin{array}{l}20-40 \% \text { reduction (in-cylinder } \\
\text { reduction) }\end{array}$ \\
\hline Particulate matter & $\begin{array}{l}95-99.5 \% \text { reduction (to meet proposed } \\
\text { California off-road staridards) }\end{array}$ \\
\hline Cost & $<\$ 20 / h p-y r$ \\
\hline Size of Emission Control Module & $<8^{\prime} \times 10^{\prime} \times 10^{\prime}$ \\
\hline Weight & $<2$ toris \\
\hline Load range & Idle $-100 \%$ \\
\hline Load transients & TBD \\
\hline Vibration loads & TBD \\
\hline Change in orientation & $\begin{array}{l} \pm 9^{\circ} \text { from horizontal (for mine-haul } \\
\text { truck) }\end{array}$ \\
\hline
\end{tabular}

For each of the two high-speed engine applications, adequate emission control can most likely be achieved through: in-cylinder $\mathrm{NO}_{x}$ control; coal cleaning and post-combustion $\mathrm{SO}_{2}$ removal; and a two-component particle removal scheme, such as a cyclone followed by a fabric filter. Since the flyash from coal-fueled diesels operating on highly beneficiated coals contain a large percentage of carbon (e.g., 50-70\%), the feasibility of periodic incineration of captured particulate matter must be considered.

Table 6 shows the itemized equipment list for the hypothetical coal engine emission system which meets these specifications. Two configurations are illustrated for comparison; the differences are not great. Estimated costs are given for a 2,000 hp engine (mine-haul truck) and a pair of 1,000 hp engines feeding a similar system (towboat). The emission system is estimated to cost $\$ 93,500$ to $\$ 111,600$ without installation, depending on the application. 
Tablo 6: Estlmated Equipment Cost

DDC/2000 HP CFD Engino Fuol Handilng and Emission Control System (Particulate and SO, Romoval)

\begin{tabular}{|c|c|c|c|c|c|}
\hline \multirow[b]{2}{*}{ (In Jan 1991 Dollars) } & \multicolumn{3}{|c|}{ Towbost $(1,000 \mathrm{Hp} \times 2)^{m}$} & \multicolumn{2}{|c|}{$\begin{array}{c}\text { Mine-Haul Truck } \\
(2,000 \mathrm{hp})^{m}\end{array}$} \\
\hline & $\begin{array}{l}\text { Fabrle } \\
\text { Flliers }\end{array}$ & $\begin{array}{l}\text { Horlzontal } \\
\text { Cartridge } \\
\text { Filiore }\end{array}$ & $\begin{array}{l}\text { Croses-Flow } \\
\text { Filtors }\end{array}$ & $\begin{array}{l}\text { Horlzontal } \\
\text { Cartridge } \\
\text { Fillere }\end{array}$ & Crose-Flow Filiers \\
\hline $\begin{array}{l}\text { Emission Control System } \\
\text { Dust Collactor }\end{array}$ & $34,400^{(1)}$ & $27,400^{(4)}$ & $\begin{array}{c}51,200 \text { (filters) } \\
29,600 \text { (housing, otc.) }\end{array}$ & $27,400^{(4)}$ & $\begin{array}{l}51,200 \text { (filters) }^{(2)} \\
29,600 \text { (housing. }^{\text {otc.) }} \\
\text { ely) }\end{array}$ \\
\hline $\begin{array}{l}\text { Dry Sorbent Injection } \\
\text { System } \\
\end{array}$ & 33,000 & 33,000 & & 33,000 & \\
\hline Heat Exchanger (760F/350F) & 15,000 & 15,000 & None & 36,000 & None \\
\hline $\begin{array}{l}\text { Compressed Air System for } \\
\text { Pulse Air Cleaning }\end{array}$ & 5,000 & 5,000 & 5,000 & 5.000 & 5,000 \\
\hline Subtotal & 87,400 & 80,400 & 85,800 & 101,400 & 85,800 \\
\hline $\begin{array}{l}\text { Duct Work, Piping (water/air) } \\
\text { and Insulation }\end{array}$ & 6,100 & 6,100 & 4,500 & 3,000 & 2,300 \\
\hline Control and Instrumentation & (included) & 7,200 & 3,800 & 7,200 & 3,800 \\
\hline Emission Total & 93,500 & 93.700 & 94,100 & 111,600 & 91,900 \\
\hline $\begin{array}{l}\text { Coal Water Slumy Fuel System } \\
\text { Fuel Storage Tank } \\
\text { Modification (0) }\end{array}$ & 6,000 & 6,000 & 6,000 & 4,000 & 4,000 \\
\hline Fuel Circulation Pump & 5,000 & 5,000 & 5,000 & 3,000 & 3,000 \\
\hline Fuel Transfer Pump & 2,000 & 2,000 & 2,000 & & \\
\hline Subtotal & 13,000 & 13,000 & 13,000 & 7,000 & 7,000 \\
\hline Piping and Instrumentation & 1,500 & 1,500 & 1,500 & 1,000 & 1,000 \\
\hline Control and Instrumentation & 1,300 & 1,300 & 1,300 & 700 & 700 \\
\hline Fuel Total & 15,800 & 15,800 & 15,800 & 8,700 & 8,700 \\
\hline Total Capital Cost & 109,300 & 109,500 & 109,900 & 120,300 & 100,600 \\
\hline Installation Cost & 16,400 & 16,400 & 16,500 & 18,000 & 15,000 \\
\hline Total Installed cost & 125,700 & 125,900 & 126,400 & 138,300 & 115,600 \\
\hline Eartiest Commercial Availability & $1893-1994$ & $1993-94$ & $\begin{array}{c}1993 \text { (partic. only) } \\
1998 \text { (partic. \& SO } \text { SO } \text { ) }\end{array}$ & $1993-94$ & $\begin{array}{c}1993 \text { (partic. only) } \\
1998 \text { (partic. \& SO, } \\
\end{array}$ \\
\hline
\end{tabular}


Table 6: Estlmated Equipment Cost (Continued)

DDC/2000 HP CFD Englne Fuel Handling and Emlesion Control System

(Partleulato and SO $_{\mathrm{x}}$ Removal)

\section{Notes}

1. Hems included:

housing, hopper, bages, suport frame rotary air lock, contrl and insulation pulse air cleaning system

Specs:

$350^{\circ} F, 8250$ ACFM

Air/cloth $=6.0 \mathrm{pm}$

92 bages, 6" dia, 10' long, woven fiberglass

Total cloth area $=1,375 \mathrm{ft}^{2}$

Overall size (hopper excluded) - 6'x10'x14'

2. Hems included: $\quad 64$ ceramic fitters with $0.3 \mathrm{~cm}$ CuO layer for $5 O_{x}$ removal, unit element $\operatorname{cost~@~} \$ 800$

Specs: $\quad 700^{\circ} \mathrm{F}, 11820$ ACFM

64 elements, approach velocity $=15 \mathrm{fpm}$

$12 \mathrm{ft}^{2}$ per element, total area $-778 \mathrm{ft}^{2}$

Regeneration cycle $=4$ days (32 hours)

3. Items included: ceramic filter module (16 elements)

housing (4 modules)

hopper, insulation

backflush cleaning system

Specs: $\quad$ Overall size $\approx 5^{\prime} \times 5^{\prime} \times 5^{\prime}$ (hopper excluded)

4. Hems included: 24 cartridge filters

horizontal housing

hopper insulation

pulse jot cloaning system

Specs: $\quad 350^{\circ} \mathrm{F}, 8250$ ACFM

air/cloth $=10 \mathrm{fpm}, 24$ cartridge filters

fiberglass cloth, $36 \mathrm{t}^{2}$ per cartridgo

overall size $\approx 5-1 / 2^{\prime} \times 4^{\prime} \times 7$ (hopper excluded)

5. Sorbent $=$ Sodium Bicarbonate

Sorbent consumption $-58 \mathrm{lb} / \mathrm{hr}$

Sulfur content in fuel (CWS) $=0.5 \%$

$\mathrm{SO}_{2}$ loading $=22 \mathrm{lb} / \mathrm{hr}$

6. Truck fuel tank: Existing loft 300 gal tank for diesel fuel ( $20 \%$ of total fuel storage capacity)

Enlarged right tank 2,000 gal for CWS (8 hour engine full bad operation)

Towboat: Existing fuel tank, 22,000 gal total capacity.

Modify the tank into two compartments:

(1) $4,400 \mathrm{gal}$ ( $20 \%$ of total capacity) for diesel fuel

(2) $17,600 \mathrm{gal}$ ( $80 \%$ of total capacity) for CWS ( 70 hours of engine full bad operation)

7. Engine specs:

Power output $=2,000 \mathrm{hp}$

Full load speed $=1,900 \mathrm{rpm}$

Cylinders $=16$ ( 8 cylinders for $1,000 \mathrm{hp} \mathrm{diesel}$ )

Compression ratio $=15$

Type $=$ 2-stroke

Aspiration: turbocharged

Fuel = CWS, 7,700 Btu/b

Fuel consumption $=250 \mathrm{gal} / \mathrm{hr}(37.3 \mathrm{lb} / \mathrm{min})$

Exhaust temperature $=700^{\circ} \mathrm{F}$ (after turbocharger)

Exhaust flow $=5,400$ SCFM 


\subsection{Engine Spreadsheet Model for Llfecycle Costs}

A Lotus 1-2-3 spreadsheet model was developed to analyze the total lifecycle cost of using the DDC 149 Coal Engine under various assumptions. The spreadsheet model includes all aspects affecting the cost of owning and operating an engine, including:

(a) source coal costs including transportation

(b) capital and operating costs of slurry plant by coal type and city of interest

(c) engine capital costs including installation

(d) maintenance costs including parts replacement intervals

(e) emission control costs (capital and operating)

Both coal-fired and oil-fired engines are analyzed in the cost calculation tables. The model takes the user specified input parameters and constants and estimates (1) the engine and emissions capital costs, (2) the engine and emissions operating costs, and (3) the maintenance costs in dollars per year (\$/year) for the oil and coal engines. These costs are totalled and the difference between these values determines the cost savings realized by using the coal engine for a given application and a given scenario.

The alternate scenarios are based on varying the parameters of interest related to the coal engine, such as

- load factor (full load hours per year)

- fuel oil price

- financing terms

- engine efficiency

In each of the model runs, the Base Case for the oil-fired engine represented \$.60/gal oil costs, which represents typical costs of diesel fuel in 1991. Scenario 1 for the oil-fired engine represented \$1.10/gal oil costs, which might be anticipated in the next 5 to 15 years when oil prices rise, and when the coal engine becomes available. The oil-fired engine efficiency over the duty cycle was arbitrarily set at $34 \%$. By way of explanation, the DDC Series 149 engine over a duty cycle for the mine-haul truck or towboat may range from $32 \%$ to $37 \%$ (HHV), depending on the amount of part load and idle operation. (Note: engine manufacturers conventionally quote efficiency based on lower heating value in terms of LHV). The DDC-149 engine has a peak efficiency of $40 \%$ (LHV), and the operating efficiency over the duty cycle would range from 34 to $39 \%$ (LHV). Separate runs of the model were made for each assumed load factor. For example, in the case of the parameter nozzle life, a single run of the spreadsheet at an assumed load factor calculates the cost saving results assuming either a low (short) nozzle life or a high nozzle life of the coal engine, both compared against a low and high oil price. 


\subsection{Input Definition}

The spreadsheet model uses several user-defined input parameters. Table 7 is a list of the input parameters, the data type of each parameter and an example of the data. The database included in the spreadsheet contains data which is specific to certain coal types and slurry plant types. Brief description of the input parameters is presented in Table 7.

Table 7: User Input Paramoters

\begin{tabular}{|c|c|}
\hline Paramoter & Data Type (Examplo) \\
\hline Coal Type & Number 1 - $12(6)$ \\
\hline Slurry Plant Typo & Name (AMAX) \\
\hline $\begin{array}{l}\text { Load Factor on all Engines (equivalent full } \\
\text { load) }\end{array}$ & Percent $(25 \%)$ \\
\hline Engine Fleet Site (Fuel Depot) & Name (Pittsburgh) \\
\hline Emissions Control Configuration Code & Letter Designator (D) \\
\hline Engine Configuration & Name (1.8MW DDC) \\
\hline Ash Level $(1=0.5 \%, 2=1 \%+)$ & 1 or $2(2)$ \\
\hline Coal Diesel Efficiency (HHV) & Percent ( $34 \%$ was assumed) \\
\hline Financing Interest Rate & Percent (12\%) \\
\hline Financing Terms (years) & Number (20) \\
\hline Fuel Oil Cost \$MMBTU (HHV) & Number (\$7.72) \\
\hline Diesel Oil Engine Efficiency (HHV) & Percent (34\% was assumed)" \\
\hline Transportation Rates SHon & Number $(\$ 10.75)$ \\
\hline Coal Recovery, $\%$ by weight & Percent $(86 \%)$ \\
\hline
\end{tabular}

-DDC Series 149 average engine efficiency over the duty cycle may range from $32 \%$ to as high as $37 \%$ (HHV), depending on the amount of part load and idle operation.

\section{- Coal Type}

A coal properties database containing information about different coals that could be used in an analysis, such as the BTU/LB (HHV) and cost per ton, is included in the spreadsheet model. A value between 1 and 12 is used to determine which coal is to be used in the analysis. The coal properties database can be modified and/or updated as necessary by the user.

\section{- Slurry Plant Type}

The type of slurry plant assumed in the analysis is input here for documentation (physical or chemical cleaning, number of tons per day processed). The data used for slurry plant costs depends on the type of plant defined here. A separate spreadsheet developed by AMAX and Arthur D. Little was used to generate this data (see Section 6.5). 


\section{- Engine Load Factor}

The Engine Load Factor is the equivalent fraction of available time, expressed in percent, that the engine was assumed to be running at full load. To simplify the analysis, it was assumed that all operation was at full rated load. It is used in conjunction with available time to determine the number of full-load equivalent hours per year the engine is run. This allows the model to determine the power generated (in MWH) over the engine's life. The number of full-load equivalent hours is also used to determine the parts replacement cycles used to determine the maintenance costs over the life of the engine.

\section{- Engine Fleet Site}

The Engine Fleet Site parameter is the city where the coal engine is assumed to be refueled. The slurry plant is assumed to be located in the same city as the engine fleet site. The name of the city, along with the type of coal, is used by the model to look up the cost of coal and the slurry plant coal cleaning and capital costs, using the database of coal cleaning and capital costs found in the spreadsheet model.

\section{- Emissions Control Configuration Code}

The spreadsheet model contains an Emissions Control Subsystem Cost section which allows the user to specify the capital and operating costs of various emissions control systems. These costs are defined by the user for the different systems that are to be used in the analysis. A single letter code is used by the user to distinguish which system is to be used in the analysis. Using this code and the Engine Configuration name (see the next parameter), the model will extract the appropriate costs and use them to determine the total cost of the coal engine system.

\section{- Engine Configuration Code}

The Emissions Control Subsystem Cost section of the spreadsheet model is set up to allow the extraction of capital and operating costs of the proposed emissions system based on the type of emissions system and the engine configuration. The user can define the codes used in this section of the spreadsheet to identify the different engine configurations.

\section{- Ash Level}

The slurry plant capital and operating cost section of the spreadsheet model contains entries for minimum ash $(0.5 \%)$ and moderate ash (1\% and up). The minimum ash case corresponds to chemical cleaning, whereas the moderate ash case corresponds to physical cleaning for most source coals. Entering a " 1 " selects coal cleaning costs associated with minimum ash from this table and entering a "2" selects clean cleaning costs associated with moderate ash (physical cleaning is less costly). 


\section{- Coal Diesel Engine Efriciency}

The coal diesel engine efficiency (HHV basis) is entered as a percent and is used to determine the amount of fuel that would be used by the engine to produce specified power output. The amount of fuel used by the engine is used to determine the operating cost of fuel per year for the coal engine. DDC Model 149 average engine efficiency over the duty cycle may range from $30 \%$ to as high as $38 \%$ (HHV), depending on the amount of part load and idle operation. A nominal value of $34 \%$ (HHV) was assumed for most runs. This is equivalent to $36 \%$ (LHV), which is stated in terms that engine manufacturers conventionally use.

\section{- Financing Interest Rate}

The financing interest rate is the rate used to determine the annual cost of repaying the capital to purchase the engine. It is used in the calculations for the oil-fired and the coal engines.

\section{- Financing Term}

The financing term is the number of years that the owner is assumed to take to pay for the engine. In the spreadsheet model, the assumption is made that the life of the engine and the financing term are equivalent. This is done to simplify the cost analysis by making the calculations tax neutral (20 years was assumed).

\section{- Fuel Oil Cost}

The assumed fuel oil cost is input in \$/MMBTU. The cost is used to determine the cost of fuel for running the oil-fired engine. In addition, several runs were made with the coal-fired engines using a small amount of diesel fuel for pilot and/or during idle. In those runs, this cost was used to determine the combined fuel cost on a weighted basis.

\section{- Diesel Engine Efficiency}

The efficiency of the diesel engine (HHV basis) is input as a fercent and is used to calculate the amount of fuel required to run the oil-fired engine, and hence the operating cost per year associated with fuel. DDC Model 149 average engine efficiency over the duty cycle may range from $30 \%$ to as high as $38 \%$ (HHV), depending on the amount of part load and idle operation.

\section{- Transportation Rates}

The mine to slurry plant transportation rates, in \$/ton, are input to determine the cost of transporting the coal from the mine to the slurry plant. 


\section{- Coal Recovery}

Each process for cleaning and turning the coal into a slurry has an assumed recovery rate which is used by the model to determine how much actual coal must be delivered from the mine to provide the desired amount of coal slurry to the engine fleet. This value was determined from the AMAX/ADL Coal Slurry Fuel Plant model (see Section 6.5).

\subsection{Coal Slurry Cost Summary}

The Coal Slurry Cost Summary section of the spreadsheet model presents the itemized costs of the coal, slurry plant operations and slurry plant capital costs. Table 8 is an example of this table. These costs are presented in dollars per million BTU higher heating value (\$/MMBTU). The individual costs are totaled and reported in the Annual Coal-Fired Engine Capital and Operating Costs table which collects all the operating and capital costs and presents them in units of \$/year.

Table 8: SLURRY COST SUMMARY

\begin{tabular}{lcc}
\multicolumn{1}{c}{ DESCRIPTION } & UNIT OF & MASE \\
\hline MEASURE & CASE \\
\hline DELIVERED COAL PRICE & \$MMBTU, HHV & $\$ 1.79$ \\
TOTAL OPNS COST (EXCL COAL) & \$MMBTU, HHV & $\$ 1.21$ \\
CAPITAL RECOVERY & \$MMBTU, HHV & $\$ 0.46$ \\
TOTAL SLURRYY COST & \$MMBTU, HHV & $\$ 3.47$ \\
\hline
\end{tabular}

The delivered coal price is made up of the cost of the coal at the minemouth and the transportation cost to the slurry plant. The operations and capital costs of the slurry plant (excluding the coal costs) are determined from the data entered in the Slurry Plant Operating and Capital Cost table. For the analyses performed in this work, the data is taken from specific runs made using the AMAX/ADL Coal-water Slurry Fuel Plant Model (see Section 2.1).

\subsection{Coal Engine Capltal Cost}

The Coal Engine Capital Cost section of the spreadsheet model uses financial statistics, operating statistics, and the capital cost of the components of the engine including the emissions equipment costs and determines an annual capital charge in dollars per year (\$/year). The annual capital charge is converted to a cost per output ( $\$ / \mathrm{kWh})$ and then apportioned as engine costs and emissions costs in $\$ / \mathrm{kWh}$. Table 9 displays the coal engine capital cost information.

The model uses the input finance rate and finance term along with the component costs to determine the annual capital charge. The power rating of the engine, life of the 
engine, availability and load factor all contribute to calculating the power generated over the life of the engine, rounded to the nearest $1,000 \mathrm{MWH}$. The power generated is used to convert from $\$ / y e a r$ to $\$ / k W h$.

\subsection{Coal Engine Maintenance Costs}

The Coal Engine Maintenance Cost section in the spreadsheet model uses the maintenance intervals of major components of the engine in hours/cycle and cost per maintenance service for each of the engine components, and the life of the engine to determine the number of maintenance cycles (parts replacement) for each component and the life cost. The total maintenance cost in dollars per engine life is converted into a cost in dollars per $\mathrm{kWh}$. Table 10 displays an example of the coal engine maintenance cost section. 
Table 9: Coal-Fueled Engine Capltal Cost per 1.5 MW Englne

\begin{tabular}{|c|c|c|}
\hline DESCRIPTION & UNITS & BASE CASE \\
\hline \multicolumn{3}{|l|}{ FINANCIAL STATISTICS } \\
\hline COST OF CAPITAL & $\%$ & $12.00 \%$ \\
\hline RECOVERY/ TERM & years & 20 \\
\hline \multicolumn{3}{|l|}{ OPERATING STATISTICS } \\
\hline POWER RATING & MEGAWATTS & 1.5 \\
\hline ANALYSIS PERIOD & years & 20 \\
\hline AVAILABILITY & $\%$ & $90.00 \%$ \\
\hline LOAD FACTOR & $\%$ & $40.00 \%$ \\
\hline FULL LOAD EQUIV. HOURS & HRS PER year & 3154 \\
\hline POWER GENERATED & MWH & 95,000 \\
\hline \multicolumn{3}{|l|}{ CAPITAL COST COMPONENTS } \\
\hline LUBE SYSTEM & & $\$ 8,000$ \\
\hline PISTONS \& PISTON RINGS & & $\$ 21,300$ \\
\hline CYLINDER LINERS & & $\$ 8,800$ \\
\hline CYLINDER HEAD & & $\$ 28,800$ \\
\hline VALVES & & $\$ 9,600$ \\
\hline FUEL PUMP \& INJECTOR & & $\$ 16,400$ \\
\hline INSTRUMENTS/CONTROLS & & $\$ 15,000$ \\
\hline TURBOCHARGER & & $\$ 15,300$ \\
\hline CAM SHAFT \& BEARINGS & & $\$ 7,600$ \\
\hline MISCELLANY & & $\$ 34,650$ \\
\hline SUBTOTAL CRITICAL PARTS & & $\$ 165,450$ \\
\hline NON-CRITICAL PARTS & & $\$ 123,000$ \\
\hline PRODUCTION ENGINE COST & & $\$ 288,450$ \\
\hline INSTALLATION COSTS & & $\$ 144,225$ \\
\hline INSTALLED ENGINE COST & & $\$ 432,675$ \\
\hline EMISSIONS EQUIPMENT & & $\$ 130,000$ \\
\hline TOTAL CAPITAL OUUTLAY & & $\$ 562,675$ \\
\hline ANNUAL CAPITAL CHARGE & \$lyear & $\$ 75,330$ \\
\hline \multicolumn{3}{|l|}{ CAPITAL CHARGEJOUTPUT } \\
\hline PRINCIPAL COMPONENT & $\$ / k W h$ & $\$ 0.0059$ \\
\hline COST OF CAPITAL & $\$ / k W h$ & $\$ 0.0099$ \\
\hline TOTAL CHARGENUTPUT & $\$ / k W h$ & $\$ 0.0159$ \\
\hline \multicolumn{3}{|l|}{ TOTAL CAPITAL COSTIOUTPUT } \\
\hline ENGINE & $\$ / k W h$ & $\$ 0.0122$ \\
\hline EMISSIONS & $\$ / k W h$ & $\$ 0.0037$ \\
\hline
\end{tabular}


Table 10: Coal Engine Malntenance Cost

\begin{tabular}{|c|c|c|}
\hline DESCRIPTION & UNITS & BASE CASE \\
\hline $\begin{array}{l}\text { MAINTENANCE INTERVALS } \\
\text { OILFUELAIR FILTER } \\
\text { INJECTOR REPLACEMENT } \\
\text { TOP END OVERHAUL } \\
\text { MANOR OVERHAUL } \\
\text { BLOCK OVERHAUL } \\
\end{array}$ & $\begin{array}{l}\text { HRS/CYCLE } \\
\text { HRS/CYCLE } \\
\text { HRS/CYCLE } \\
\text { HRS/CYCLE } \\
\text { HRS/CYCIEE } \\
\end{array}$ & $\begin{array}{r}250 \\
500 \\
8,000 \\
20,000 \\
40,000 \\
\end{array}$ \\
\hline $\begin{array}{l}\text { COST PER SERVICING } \\
\text { OILFUEUAIR FILTER } \\
\text { INJECTOR REPLACEMENT } \\
\text { TOP END OVERHAUL } \\
\text { MAJOR OVERHAUL } \\
\text { BLOCK OVERHAUL } \\
\end{array}$ & $\begin{array}{l}\$ \\
\$ \\
\$ \\
\$ \\
\$\end{array}$ & $\begin{array}{r}\$ 300 \\
\$ 4,000 \\
\$ 20,000 \\
\$ 40,000 \\
\$ 80,000 \\
\end{array}$ \\
\hline $\begin{array}{l}\text { SERVICING THRU } 1 \text { st REBUILD } \\
\text { OILFUELAIR FILTER } \\
\text { INJECTOR REPLACEMENT } \\
\text { TOP END OVERHAUL } \\
\text { MANOR OVERHAUL } \\
\text { BLOCK OVERHAUL } \\
\end{array}$ & $\begin{array}{l}\text { \# OF CYCLES } \\
\text { \# OF CYCLES } \\
\text { \# OF CYCLES } \\
\text { \# OF CYCLES } \\
\text { \# OF CYCLES } \\
\end{array}$ & $\begin{array}{r}160 \\
80 \\
5 \\
2 \\
1 \\
\end{array}$ \\
\hline $\begin{array}{l}\text { COST THRU 1st REBUILD } \\
\text { OILFUELAIR FILTER } \\
\text { INJECTOR REPLACEMENT } \\
\text { TOP END OVERHAUL } \\
\text { MAJOR OVERHAUL } \\
\text { BLOCK OVERHAUL } \\
\text { TOTAL THRU } \# 1 \text { BOTTOM END } \\
\end{array}$ & $\begin{array}{l}\$ \\
\$ \\
\$ \\
\$ \\
\$ \\
\$\end{array}$ & $\begin{array}{r}\$ 48,000 \\
\$ 320,000 \\
\$ 100,000 \\
\$ 80,000 \\
\$ 80,000 \\
\$ 628,000 \\
\end{array}$ \\
\hline $\begin{array}{l}\text { ALLOCATED MAINTENANCE \% } \\
\text { OILFUELAIR FILTER } \\
\text { INJECTOR REPLACEMENT } \\
\text { TOP END OVERHAUL } \\
\text { MANOR OVERHAUL } \\
\text { BLOCK OVERHAUL } \\
\end{array}$ & $\begin{array}{l}\% \\
\% \\
\% \\
\% \\
\% \\
\end{array}$ & $\begin{array}{r}7.64 \% \\
50.96 \% \\
15.92 \% \\
12.74 \% \\
12.74 \% \\
\end{array}$ \\
\hline $\begin{array}{l}\text { LIFE SERVICE CYCLES } \\
\text { OIUFUEUAIR FILTER } \\
\text { INJECTOR REPLACEMENT } \\
\text { TOP END OVERHAUL } \\
\text { MAJOR OVERHAUL } \\
\text { BLOCK OVERHAUL } \\
\end{array}$ & $\begin{array}{l}\text { \# OF CYCLES } \\
\text { \# OF CYCLES } \\
\text { \# OF CYCLES } \\
\text { \# OF CYCLES } \\
\text { \# OF CYCLES } \\
\end{array}$ & $\begin{array}{r}252 \\
126 \\
7 \\
3 \\
1 \\
\end{array}$ \\
\hline $\begin{array}{l}0 \text { year COST } \\
\text { OILFUELAIR FILTER } \\
\text { INJECTOR REPLACEMENT } \\
\text { TOP END OVERHAUL } \\
\text { MANOR OVERHAUL } \\
\text { BLOCK OVERHAUL } \\
\end{array}$ & $\begin{array}{l}\text { \$LIFE } \\
\text { \$LLIFE } \\
\text { \$NLIFE } \\
\text { \$LIFE } \\
\text { \$LIFE } \\
\end{array}$ & $\begin{array}{r}\$ 75,600 \\
\$ 504,000 \\
\$ 140,000 \\
\$ 120,000 \\
\$ 80,000 \\
\end{array}$ \\
\hline TOTAL MAINTENANCE COST & $\begin{array}{l}\text { \$RIFE } \\
\$ / k W r\end{array}$ & $\begin{array}{r}\$ 919,600 \\
\$ 0.0097 \\
\end{array}$ \\
\hline
\end{tabular}


The model determines the number of cycles for the maintenance of each component by dividing the number of hours between maintenance cycles into the number of operating hours determined from the life of the engine, the availability and load factor. Obviously the model assumes that the final maintenance cycle for a component is not made when the engine reaches the end of its useful life.

\subsection{Coal Engine Fuel Cost}

The spreadsheet model calculates the coal engine fuel cost by summing the slurry plant capital cost, the slurry plant operations cost excluding the coal, the delivered coal cost and the transportation cost for the slurry. The slurry plant capital cost and operations cost are extracted from the slurry plant database built into the spreadsheet model. The coal price is determined from the calculated amount of coal to be used by the engine, including the coal lost due to cleaning, and the transportation cost for transporting the coal from the mine to the slurry plant. Table 11 displays an example of the coal engine fuel cost section of the spreadsheet model. This is an alternative way to display the same information as Table 8, but incorporates engine efficiency.

Table 11: Coal Engine Fuel Cost

\begin{tabular}{llr}
\hline \multicolumn{3}{c}{ COAL-FIRED ENGINE FUEL COST } \\
\hline DESCRIPTION & UNITS & BASE CASE \\
\hline SLURRY OPNS INCL COAL COST & & \\
CAPITAL RECOVERY & $\$ k W h$ & $\$ 0.0047$ \\
OPNS COST (EXCL COAL) & $\$ k W h$ & $\$ 0.0121$ \\
DELIVERED COAL PRICE & $\$ k W h$ & $\$ 0.0180$ \\
TOTAL CAPITAL \& OPNS & $\$ k W h$ & $\$ 0.0348$ \\
SLURRY TRANSPORTATION COST & $\$ k W h$ & $\$ 0.0027$ \\
TOTAL FUEL COMPONENT & $\$ k W h$ & $\$ 0.0374$ \\
\hline
\end{tabular}

\subsection{Total Coal FIred EngIne Capltal and Operating Costs}

The coal engine capital and operating costs on a dollars per year basis are summarized in the Annual Coal Engine Capital and Operating Costs section of the spreadsheet model. A similar section of the spreadsheet model is generated on a dollars per $\mathrm{kWh}$ basis as well. These sections contain the operating and capital costs of the engine excluding emissions costs, and the operating and capital costs of the emissions system. A total cost is calculated and can be compared with the total cost for the oil-fired engine to determine the cost benefit for using coal-fired engines in place of oil-fired engines for the specific scenarios setup by the user. Table 12 displays an example of the coal engine capital and operating costs on a $\$ / \mathrm{kWh}$ basis. Table 13 displays the same information on a \$/year basis. 
Table 12: Coal Engine Capltal and Operating Cost (In \$/kWh)

\begin{tabular}{llr}
\hline DESCRIPTION & UNITS & BASE CASE \\
\hline OPERATING (EXCL EMISSIONS) & & \\
FUEL & $\$ k W h$ & $\$ 0.0374$ \\
MAINTENANCE & $\$ k W h$ & $\$ 0.0097$ \\
TOTAL OPERATING & $\$ k W h$ & $\$ 0.0471$ \\
\hline CAPITAL (EXCL EMISSIONS) & $\$ k W h$ & $\$ 0.0122$ \\
EMISSIONS & & \\
$\quad$ OPERATING & $\$ k W h$ & $\$ 0.0100$ \\
CAPITAL & $\$ / k W h$ & $\$ 0.0037$ \\
TOTAL EMISSIONS & $\$ k W h$ & $\$ 0.0137$ \\
\hline TOTAL COST & $\$ / k W h$ & $\$ 0.0730$ \\
& $\$ / y e a r$ & $\$ 346,668$ \\
\hline
\end{tabular}

Table 13: Coal Engine Capital and Operating Cost (In \$/year)

\begin{tabular}{llr}
\hline DESCRIPTION & UNITS & BASE CASE \\
\hline OPERATING (EXCL EMISSIONS) & & \\
$\quad$ FUEL & $\$$ year & $\$ 177,858$ \\
MAINTENANCE & $\$$ Nyear & $\$ 45,980$ \\
TOTAL OPERATING & $\$$ Nyear & $\$ 223,838$ \\
\hline CAPITAL (EXCL EMISSIONS) & $\$$ year & $\$ 57,926$ \\
EMISSIONS & & \\
OPERATING & $\$$ year & $\$ 47,500$ \\
CAPITAL & $\$$ year & $\$ 17,404$ \\
TOTAL EMISSIONS & $\$$ Nyear & $\$ 64,904$ \\
\hline TOTAL COST & $\$$ \$year & $\$ 346,668$ \\
\hline
\end{tabular}

In the analysis section of this report, comparisons of the total cost per year between coal-fired and oil-fired engines are made to determine the cost savings that can be realized based on parametric analyses of nozzle life, coal cleaning costs, financing interest rates. The parametric analyses are performed for a mine-haul truck fleet assumed to be located in Salt Lake region and an inland waterway tow boat assumed to be refueled in the Pittsburgh area.

\subsection{Oll-FIred EngIne Capital Costs}

The oil-fired engine capital cost section of the spreadsheet model uses financial statistics, operating statistics and capital costs of the engine components to determine an annual capital charge over the life of the engine. The capital charge is converted to dollars per $\mathrm{kWh}$ and is used in the oil-fired capital and operating cost cable. The power 
generated by the oil-fired engine over its life is calculated in the same manner as for the coal engine above. Table 14 displays an example of the oil-fired diesel engine capital cost section of the spreadsheet model.

Table 14: Oll-Fired Dlesel Engine Capltal Cost

\begin{tabular}{|c|c|c|}
\hline DESCRIPTION & UNITS & BASE CASE \\
\hline \multicolumn{3}{|l|}{ FINANCIAL STATISTICS } \\
\hline COST OF CAPITAL & $\%$ & $12.00 \%$ \\
\hline RECOVERY TERM & years & 20 \\
\hline \multicolumn{3}{|l|}{ OPERATING STATISTICS } \\
\hline POWER RATING & MEGAWATTS & 1.5 \\
\hline LIFE & years & 20 \\
\hline AVAILABILITY & $\%$ & $90.00 \%$ \\
\hline LOAD FACTOR & $\%$ & $40.00 \%$ \\
\hline POWER GENERATED & MW HOURS & 95,000 \\
\hline \multicolumn{3}{|l|}{ CAPITAL COST COMPONENTS } \\
\hline STANDARD ENGINE COST & $\$$ & $\$ 220,000$ \\
\hline$\%$ COST OF CRITICAL PARTS & $\%$ & $44.00 \%$ \\
\hline VALUE OF CRITICAL PARTS & $\$$ & $\$ 96,800$ \\
\hline ADJ FOR CRITICAL PARTS & $\%$ & $100.00 \%$ \\
\hline ADJ COST-CRITICAL PARTS & \$ & $\$ 96,800$ \\
\hline PRODUCTION ENGINE COST & $\$$ & $\$ 220,000$ \\
\hline INSTALLATION COSTS & $\$$ & $\$ 110,000$ \\
\hline TOTAL CAPITAL OUTLAY & $\$$ & $\$ 330,000$ \\
\hline ANNUAL CAPITAL CHARGE & \$year & $\$ 44,180$ \\
\hline \multicolumn{3}{|l|}{ CAPITAL CHARGE/OUTPUT } \\
\hline PRINCIPAL COMPONENT & $\$ / k W h$ & $\$ 0.0035$ \\
\hline COST OF CAPITAL & $\$ k W h$ & $\$ 0.0058$ \\
\hline TOTAL CHARGEOUTPUT & $\$ k W h$ & $\$ 0.0093$ \\
\hline
\end{tabular}

\subsection{Oll-Fired Englne Maintenance Costs}

The Oil-Fired Engine Maintenance Cost secti , n of the spreadsheet model uses the maintenance intervals of major components of the engine in hours/cycle and cost per maintenance service for each of the engine components, and the life of the engine to determine the number of maintenance cycles for each component and the life cost. The total maintenance cost in dollars per engine life is converted into a cost in dollars per $\mathrm{kWh}$. Table 15 displays an example of the oil-fired engine mainten?ince cost found in the spreadsheet model. 
Table 15: Olf-Fired Englne Malntenance Costs

\begin{tabular}{|c|c|c|}
\hline DESCRIPTION & UNITS & BASE CASE \\
\hline $\begin{array}{l}\text { MAINTENANCE INTERVALS } \\
\text { OILFUEUAIR FILTER } \\
\text { INJECTOR REPLACEMENT } \\
\text { TOP END OVERHAUL } \\
\text { MANOR OVERHAUL } \\
\text { BLOCK OVERHAUL }\end{array}$ & $\begin{array}{l}\text { HAS/CYCLE } \\
\text { HRS/CYCLE } \\
\text { HRS/CYCLE } \\
\text { HRS/CYCLE } \\
\text { HRS/CYCLE }\end{array}$ & $\begin{array}{r}250 \\
5,000 \\
11,000 \\
22,000 \\
60,000\end{array}$ \\
\hline $\begin{array}{l}\text { COST PER SERVICING } \\
\text { OIUFILTERVAIR FILTER } \\
\text { INJECTOR REPLACEMENT } \\
\text { TOP END OVERHAUL } \\
\text { MANOR OVERHAUL } \\
\text { BLOCK OVERHAUL }\end{array}$ & $\begin{array}{l}\$ \\
\$ \\
\$ \\
\$ \\
\$\end{array}$ & $\begin{array}{r}\$ 350 \\
\$ 6,500 \\
\$ 23,000 \\
\$ 45,000 \\
\$ 70,000\end{array}$ \\
\hline $\begin{array}{l}\text { SERVICE CYCLES THRU Ist REBUILD } \\
\text { OILFILTERIAIR FILTER } \\
\text { INJECTOR REPLACEMENT } \\
\text { TOP END OVERHAUL } \\
\text { MANOR OVERHAUL } \\
\text { BLOCK OVERHAUL }\end{array}$ & $\begin{array}{l}\text { \# OF CYCLES } \\
\text { \# OF CYCLES } \\
\text { \# OF CYCLES } \\
\text { \# OF CYCLES } \\
\text { \# OF CYCLES }\end{array}$ & $\begin{array}{r}240 \\
12 \\
6 \\
3 \\
1\end{array}$ \\
\hline $\begin{array}{l}\text { COST THRU ISt BOTTOM END REBUILD } \\
\text { OILFILTERVAIR FILTER } \\
\text { INJECTOR REPLACEMENT } \\
\text { TOP END OVERHAUL } \\
\text { MANOR OVERHAUL } \\
\text { BLOCK OVERHAUL } \\
\text { TOTAL }\end{array}$ & $\begin{array}{l}\$ \\
\$ \\
\$ \\
\$ \\
\$ \\
\$\end{array}$ & $\begin{array}{r}\$ 84,000 \\
\$ 78,000 \\
\$ 138,000 \\
\$ 135,000 \\
\$ 70,000 \\
\$ 505,000 \\
\end{array}$ \\
\hline $\begin{array}{l}\text { ALLOCATED MAINTENANCE \% } \\
\text { OILFILTERAIR FILTER } \\
\text { INJECTOR REPLACEMENT } \\
\text { TOP END OVERHAUL } \\
\text { MANOR OVERHAUL } \\
\text { BLOCK OVERHAUL }\end{array}$ & $\begin{array}{l}\% \\
\% \\
\% \\
\% \\
\%\end{array}$ & $\begin{array}{l}16.63 \% \\
15.45 \% \\
27.33 \% \\
26.73 \% \\
13.86 \%\end{array}$ \\
\hline $\begin{array}{l}\text { LIFE SERVICE CYCLES } \\
\text { OILFILTER NAIR FILTER } \\
\text { INJECTOR REPLACEMENT } \\
\text { TOP END OVERHAUL } \\
\text { MANOR OVERHAUL } \\
\text { BLOCK OVERHAUL }\end{array}$ & $\begin{array}{l}\text { \# OF CYCLES } \\
\text { \# OF CYCLES } \\
\text { \# OF CYCLES } \\
\text { \# OF CYCLES } \\
\text { \# OF CYCLES }\end{array}$ & $\begin{array}{r}252 \\
12 \\
5 \\
2 \\
1\end{array}$ \\
\hline $\begin{array}{l}20 \text { yөar COST } \\
\text { OILFILTERAIR FILTER } \\
\text { INJECTOR REPLACEMENT } \\
\text { TOP END OVERHAUL } \\
\text { MANOR OVERHAUL } \\
\text { BLOCK OVERHAUL }\end{array}$ & $\begin{array}{l}\text { \$LIFE } \\
\text { \$LIFE } \\
\text { \$LIFE } \\
\text { \$LIFE } \\
\text { \$LIFE }\end{array}$ & $\begin{array}{r}\$ 88,200 \\
\$ 78,000 \\
\$ 115,000 \\
\$ 90,000 \\
\$ 70,000\end{array}$ \\
\hline TOTAL MAINTENANCE COST & $\begin{array}{l}\text { \$RIFE } \\
\$ / k W h\end{array}$ & $\begin{array}{r}\$ 441,200 \\
\$ 0.0046\end{array}$ \\
\hline
\end{tabular}


The model determines the number of cycles for the maintenance of each component by dividing the number of hours between maintenance cycles into the number of operating hours determined from the life of the engine, the availability and load factor. Obviously the model assumes that the final maintenance cycle for a component is not made when the engine reaches the end of its useful life.

\subsection{Total Oll-FIred Engine Capltal and Operating Costs}

The oil-fired engine capital and operating custs on a dollars per year basis are summarized in the Annual Oil-Fired Engine Sapital and Operating Costs section in the spreadsheet model. A similar section exists in the spreadsheet model on a dollars per $\mathrm{kWh}$ basis as well. These sections contain the operating and capital costs of the engine, the capital cost of the emissions system for the oil-fired engine, and the fuel costs. A total cost is calculated and compared with the total cost for the coal engine. Table 16 displays an example of the oil-fired engine capital and operating cost on a $\$ / \mathrm{kWh}$ basis. Table 17 displays the same information on a \$/year basis.

Table 16: Oll-Fired Engine Capltal and Operating Cost (In \$/kWh)

\begin{tabular}{llr}
\hline DESCRIPTION & UNITS & BASE CASE \\
\hline ENGINE CAPITAL & $\$ k W h$ & $\$ 0.0093$ \\
EMISSIONS CAPITAL & $\$ k W h$ & $\$ 0.0010$ \\
ENGINE MAINTENANCE & $\$ / k W h$ & $\$ 0.0046$ \\
FUEL & $\$ / k W h$ & $\$ 0.0421$ \\
TOTAL COST & $\$ k W h$ & $\$ 0.0571$ \\
\hline
\end{tabular}

Table 17: Annual OlrFired Dlesel Engine Capital and Operating Cost (in S/year)

\begin{tabular}{llr}
\hline DESCRIPTION & UNITS & BASE CASE \\
\hline ENGINE CAPITAL & $\$$ \$year & $\$ 44,180$ \\
EMISSIONS CAPITAL & $\$$ \$year & $\$ 4,686$ \\
ENGINE MAINTENANCE & $\$$ Nyear & $\$ 22,060$ \\
FUEL & $\$$ Nyear & $\$ 200,109$ \\
TOTAL COST & $\$$ Nyear & $\$ 271,035$ \\
\hline
\end{tabular}




\subsection{Analysis of Economic Feasibility}

The spreadsheet model described in the previous section was used to perform an analysis of the economic feasibility of operating a coal diesel engine in the two selected applications. The results are found in this section. More than 50 runs of the model were made, resulting in several plots comparing the cost savings per year generated by using a coal engine in place of an oil-fired engine for different assumed scenarios. In each plot, fuel oil price was the basic independent parameter used on the horizontal axis.

In Sections 1 through 5 above, various candidate applications for the DDC coal engine were evaluated. Two potentially successful engine applications were recommended for more detailed economic evaluation--they are the mine-haul truck and the inland waterway tow boat. In order to evaluate these applications, representative locations were assumed. Salt Lake was assumed to be a representative Western site for the mine-haul truck fleet (Copper mines and surface coal mines are in Arizona, New Mexico, Utah, and Powder River Basin). Pittsburgh was chosen as a typical inland waterway tow boat refueling location -- it is one of many cities on the inland waterway. The proximity of these application sites to coal sources was taken into account. The AMAX slurry plant model was run to determine slurry plant and transportation costs. Colowyo coal was used for the Salt Lake site for mine-haul trucks, due to its proximity. Blue Gem coal from Kentucky was selected in the model to determine the slurry plant and transportation costs for the Pittsburgh site for refueling tow boats.

Several parameters were modified to determine their affect on the cost savings resulting from using coal engines instead of oil-fired engines for these applications. The parameters modified and the questions answered were as follows:

- Nozzle life - how maintenance costs of critical parts affect savings,

- Coal cleaning costs - how slurry fuel costs affect savings,

- Interest rates - how the cost of money affects savings,

- Diesel fuel use - how the use of diesel fuel for idling affects savings.

- Engine efficiency - how a drop in engine efficiency would affect savings.

\subsection{Spreadsheet Input for Parametrlc Runs}

Data from several sources were used in the spreadsheet model. The AMAX Coal Slurry Plant Cost Model was run to determine the coal transportation costs and the slurry plant capital and operating costs. Table 18 lists the primary data from the AMAX/ADL model for the Pittsburgh and Salt Lake sites.

Using these input values, the AMAX/ADL Slurry Plant Model calculated the capital cost of the slurry plant, the cost of the coal, the transportation cost of the coal from the mine to the slurry plant and the operating cost of the slurry plant. Table 19 contains the values extracted from the AMAX/ADL Slurry Plant Model output and used in the engine model. 
Table 18: AMAXJADL Cost Modol Data (Assumed)

\begin{tabular}{lll}
\hline \multicolumn{1}{c}{ Parameter } & Pittsburgh Site & Salt Lake City Site \\
\hline Coal & Blue Gem & Colowyo \\
Coal Recovery & $86 \%$, By Weight & $92 \%$, By Woight \\
Coal Heating Value (HHV) & 15,100 Btu/lb & 13.720 Btulb \\
Slurry Top Size & 30 micron top & 30 micron top \\
Slurry \% Ash & $1.6 \%$ & $1.6 \%$ \\
Slurry Fuel Heating Value (HHV) & 29.7 MMBtu/ton & 27.0 MMBtu/ton \\
Process Type for Coal Cleaning & Heavy Media Separation & Oil Agglomeration \\
Operating Hours/year (slury plant) & 7000 & 7000
\end{tabular}

Table 19: AMAX/ADL Slurry Plant Model Coal and Slurry Plant Output Data

\begin{tabular}{lll}
\hline \multicolumn{1}{c}{ Cost Hem } & Pittsburgh & \multicolumn{1}{c}{ Salt Lake City } \\
\hline Purchased Coal (HHV basis) & $\$ 1.37 \mathrm{MMBtu}$ & $\$ 1.11 \mathrm{MMBtu}$ \\
Transportation to Slurry Plant & $\$ 0.42 \mathrm{MMBtu}$ & $\$ 0.63 \mathrm{MMBtu}$ \\
Operating Cost & $\$ 1.21 \mathrm{MMBtu}$ & $\$ 1.81 \mathrm{MMBtu}$ \\
Capital Cost & $\$ 131,000,000$ & $\$ 152,000,000$ \\
\hline
\end{tabular}

The output data in Table 19 was transferred to the engine model spreadsheet database and used for each site of the engine application being studied.

Engine capital cost and maintenance data for the oil and coal eng.nes was estimated by Arthur D. Little, Inc. with inputs from Detroit Diesel. Data which was not readily obtainable was estimated based on related known and anticipated costs. Installation costs for the engines and emission system was assumed to be $50 \%$ of the capital cost of the engine and emission system.

Table 20 contains a list of the assumed parameters used in some of the parametric runs for the mine-haul truck application in Salt Lake City.

Table 21 lists some of the parametric runs performed for the inland waterway tow boat application in Pittsburgh. 
Table 20: Mino-Haul Truck Paramotric Runs - Partlal Llst

\begin{tabular}{|c|c|c|c|}
\hline Run No. & $\begin{array}{c}\text { Engino } \\
\text { Efficioncy (HHV) }\end{array}$ & $\begin{array}{l}\text { Load } \\
\text { Factor }\end{array}$ & Paramoter / Values \\
\hline MHT1 & \multirow{3}{*}{$28 \%$} & $15 \%$ & \multirow{3}{*}{$\begin{array}{l}\text { Reduced Engine Efficiency and } \\
\text { Coal Cleaning / } \$ 1.21, \$ 0.61 / \mathrm{MMBtu}\end{array}$} \\
\hline MHT2 & & $25 \%$ & \\
\hline MHT3 & & $35 \%$ & \\
\hline MHT4 & \multirow{3}{*}{$34 \%$} & $15 \%$ & \multirow{3}{*}{ Coal Cleaning / \$1.21, \$0.61/MMBtu } \\
\hline MHT5 & & $25 \%$ & \\
\hline MHT6 & & $35 \%$ & \\
\hline MHTIO & \multirow{3}{*}{$34 \%$} & $15 \%$ & \multirow{3}{*}{ Nozzle Life / 500, 1.000 Hours } \\
\hline MHT11 & & $25 \%$ & \\
\hline MHT12 & & $35 \%$ & \\
\hline MHT16 & \multirow{3}{*}{$34 \%$} & $15 \%$ & \multirow{3}{*}{ Finance Pate / 12\%, 16\% } \\
\hline MHT17 & & $25 \%$ & \\
\hline MHT18 & & $35 \%$ & \\
\hline MHT2O & $34 \%$ & $25 \%$ & Diesel Fuel Use / 5\%, 10\%, 20\% \\
\hline
\end{tabular}

-Note: The assumed engine efficiency is (a) based on higher heating value and (b) represents a duty cycle rather than a peak efficiency. The value $28 \%$ is hypothetical, was not intended to be indicative of existing or future DDC engines, and was used solely to investigate the cost impact of a significant drop in engine efficiency on the economics.

Table 21: Inland Watorway Tow Boat Parametric Runs - Partial Llst

\begin{tabular}{|c|c|c|c|}
\hline Run No. & $\begin{array}{l}\text { Engine } \\
\text { Efficiency* }\end{array}$ & $\begin{array}{l}\text { Load } \\
\text { Factor }\end{array}$ & Parameter ' Values \\
\hline TB4 & \multirow{3}{*}{$34 \%$} & $30 \%$ & \multirow{3}{*}{ Coal Cleaning / \$1.21, \$0.61/MMBlu } \\
\hline TB5 & & $40 \%$ & \\
\hline TB6 & & $50 \%$ & \\
\hline TB10 & \multirow{3}{*}{$34 \%$} & $30 \%$ & \multirow{3}{*}{ Nozzle Life / 500, 1,000 Hours } \\
\hline TB11 & & $40 \%$ & \\
\hline TB12 & & $50 \%$ & \\
\hline TB16 & \multirow{3}{*}{$34 \%$} & $30 \%$ & \multirow{3}{*}{ Finance Rate / 12\%, 16\% } \\
\hline TB17 & & $40 \%$ & \\
\hline TB18 & & $50 \%$ & \\
\hline TB20 & $34 \%$ & $40 \%$ & Diesel Fuel Use / 5\%, 10\%, 20\% \\
\hline
\end{tabular}

- Note: The assumed engine efficiency is (a) based on higher heating value and (b) represents a duty cycle rather than a peak efficiency. The value $28 \%$ is hypothetical, was not intended to be indicative of existing or future DDC engines, and was used solely to investigate the cost impact of a significant drop in engine efficiency on the economics.

Each of the parametric runs generated straight lines. Selected runs have been lotted and are displayed in Figure 11-19. 


\subsection{Results for Mine-Haul Truck Application}

The mine-haul truck engine model assumes a single 2,000 hp (1.5 MW) engine. This application produced the lower yearly savings compared with the inland waterway tow boat application, for each of the parametric runs. As one would expect, the load factor has a significant effect on the yearly savings. The coal engine efficiency also has a noticeable effect on yearly savings as shown in Figure 11 versus Figure 12. Assuming a coal cleaning cost of $\$ 1.21 / \mathrm{MMBtu}$ and a coal engine efficiency of $28 \%$, the mine-haul truck application in Salt Lake City does not break even until the diesel fuel cost is approximately $\$ 1.14 / \mathrm{gal}$ (see Figure 11), whereas for the same coal cleaning cost and load iactor and a $34 \%$ engine efficiency, the break even point is $\$ 1.00$ (see Figure 12). A four percentage point improvement in efficiency yields a significant improvement in the break even point.

Flgure 11: Coal Cleaning Cost Effects for a Mine-Haul Truck with a Coal Engine Efflcloncy $=28 \%$

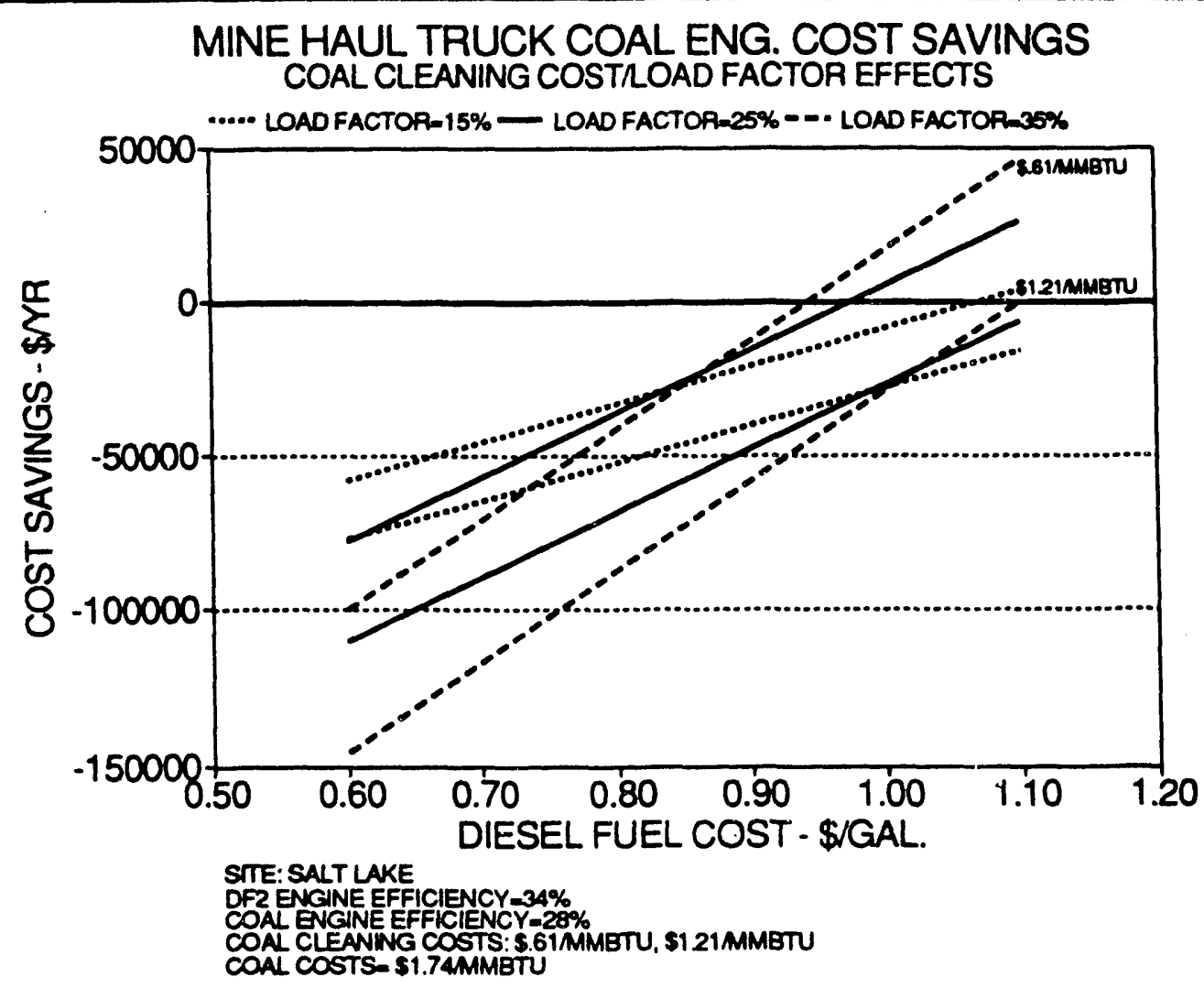

Load factor is also important: as the load factor improves from $25 \%$ to $35 \%$, the break Even cost of diesel fuel moves from $\$ 1.00 / \mathrm{gal}$. to $\$ .95 / \mathrm{gal}$. for a coal engine efficiency of $34 \%$. The oil engine efficiency for these runs is fixed at $34 \%$. At a coal engine efficiency of $34 \%$, the mine-haul truck begins to break even at a diesel fuel cost of $\$ 1.00$ 
Figure 12: Coal Cleaning Cost Effects for a Mine-Haul Truck with a Coal Engine Efficlency $=34 \%$

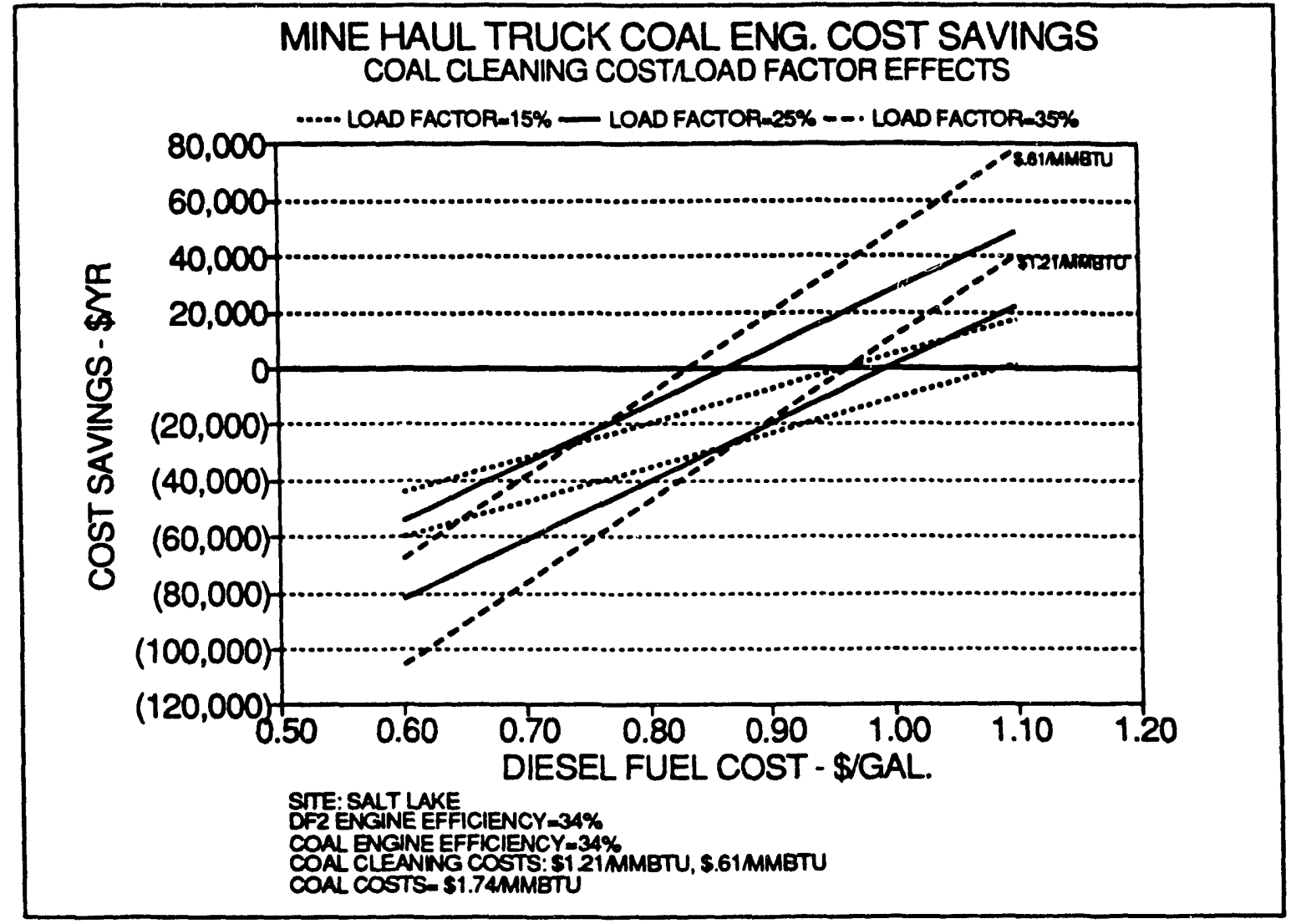

and a coal cleaning cost of $\$ 1.21 / \mathrm{MMBtu}$. Any reductions in coal cleaning costs will increase the yearly savings. Table 22 summarizes the yearly savings for a mine-haul truck in Salt Lake City for two engine efficiencies, $28 \%$ and $34 \%$, and coal cleaning costs of \$1.21/MMBtu and \$.61/MMBtu at an assumed future diesel fuel cost of $\$ 1.00 /$ gal. Figures 11 and 12 display the results of the engine model runs for coal cleaning effects.

Table 22: Coal Cleaning Cost Effects on Annual Savings for Mine-Haul Truck Diesel Fuel Cost=\$1.00/gal

\begin{tabular}{|c|c|c|c|c|}
\hline \multirow[b]{2}{*}{ Load Factor } & \multicolumn{2}{|c|}{$\begin{array}{c}28 \% \text { Engine Efficiency } \\
\text { Coal Cleaning Cost ( } \$ M M M B \text { (u) }\end{array}$} & \multicolumn{2}{|c|}{$\begin{array}{l}34 \% \text { Engine Efficiency } \\
\text { Coal Cleanina Cost ( } \$ M M \text { Btu) }\end{array}$} \\
\hline & $\$ 1.21$ & $\$ .61$ & $\$ 1.21$ & $\$ .61$ \\
\hline $15 \%$ & $(\$ 25,000)$ & $(\$ 10,000)$ & $(\$ 10,000)$ & $\$ 5,000$ \\
\hline $25 \%$ & $(\$ 25,000)$ & $\$ 10,000$ & $\$ 2,000$ & $\$ 30,000$ \\
\hline $35 \%$ & $(\$ 25,000)$ & $\$ 25,000$ & $\$ 15,000$ & $\$ 50,000$ \\
\hline
\end{tabular}


Varying the nozzle life in the engine model gives an indication of the relative effect of maintenance costs of a high wear component of the coal engine. From Figure 13 it can be seen that a doubling of the nozzle life has a smaller cost savings affect than reducing the coal cleaning in half. For a load factor of $25 \%$, the break even diesel fuel cost is reduced from $\$ .98 / \mathrm{gal}$. to $\$ .95 / \mathrm{gal}$. by doubling the nozzle life. Table 23 summarizes the yearly savings for the mine-haul truck application in Salt Lake City two nozzle life values of 500 hours and 1000 hours.

Table 23: Nozzib Life Cost Effects on Annual Savings for Mine-Haul Truck Diesel Fuel Cost=\$1.00/gal, Coal Engine Efflclency $34 \%$

\begin{tabular}{ccc}
\hline \multirow{2}{*}{ Load Factor } & 500 Nezzle Life(Hours) $^{\text {No }}$ & 1,000 \\
\cline { 2 - 3 } $15 \%$ & $(\$ 10,000)$ & $(\$ 5,000)$ \\
$25 \%$ & $\$ 2,000$ & $\$ 10,000$ \\
$35 \%$ & $\$ 15,000$ & $\$ 25,000$ \\
\hline
\end{tabular}

Figure 13: Nozzle Lffe Cost Effects for a Mine-Haul Truck

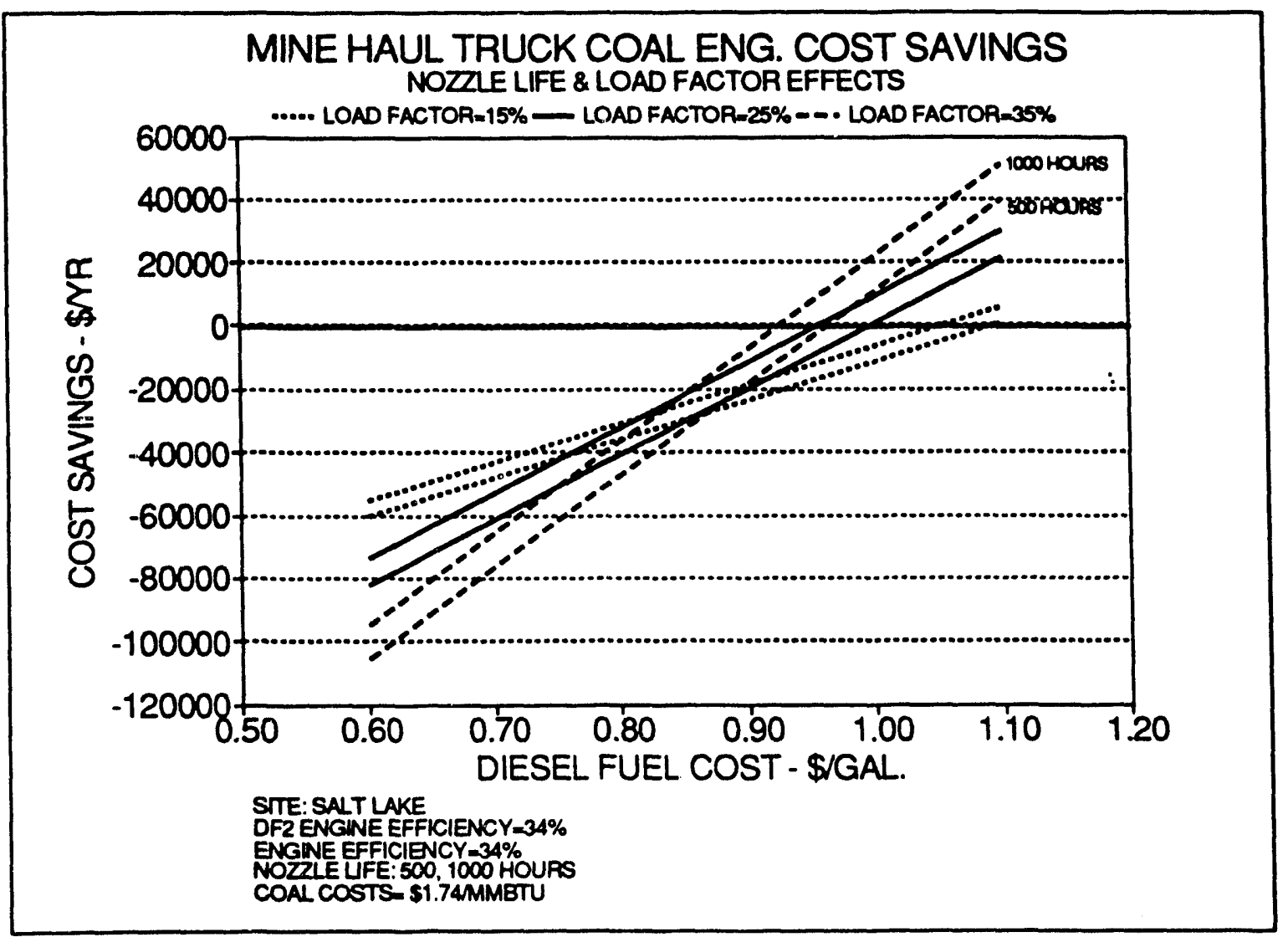


Varying the financing rate indicates the effect of the cost of money on the annual cost savings generated by using a coal engine in place of an oil-fired engine in a mine-haul truck application. For a load factor of $25 \%$ and a coal engine efficiency of $34 \%$, the diesel fuel cost break even point is $\$ .95 / \mathrm{gal}$ for an interest rate of $12 \%$. Table 24 summarizes the annual cost savings for the mine-haul truck fleet in Salt Lake City due to interest rates varying from $12 \%$ to $16 \%$. Figures 14 display the results of the engine model runs for the effects on annual savings caused by varying the financing interest rate of the engine.

Table 24: Interest Rate Effects on Annual Savings for Mine-Haul Truck Diesel Fuel Cost $=\$ 1.00 /$ gal, Coal Engine Efflclency $34 \%$

\begin{tabular}{|c|c|c|}
\hline \multirow[b]{2}{*}{ Load Factor } & \multicolumn{2}{|c|}{ Interest Rates } \\
\hline & $12 \%$ & $16 \%$ \\
\hline $15 \%$ & $\$ 0$ & $(\$ 22,000)$ \\
\hline $25 \%$ & $\$ 10,000$ & $(\$ 10,000)$ \\
\hline $35 \%$ & $\$ 21,000$ & $(\$ 2,000)$ \\
\hline
\end{tabular}

Figure 14: Interest Rate Effects for a Mine-Haul Truck

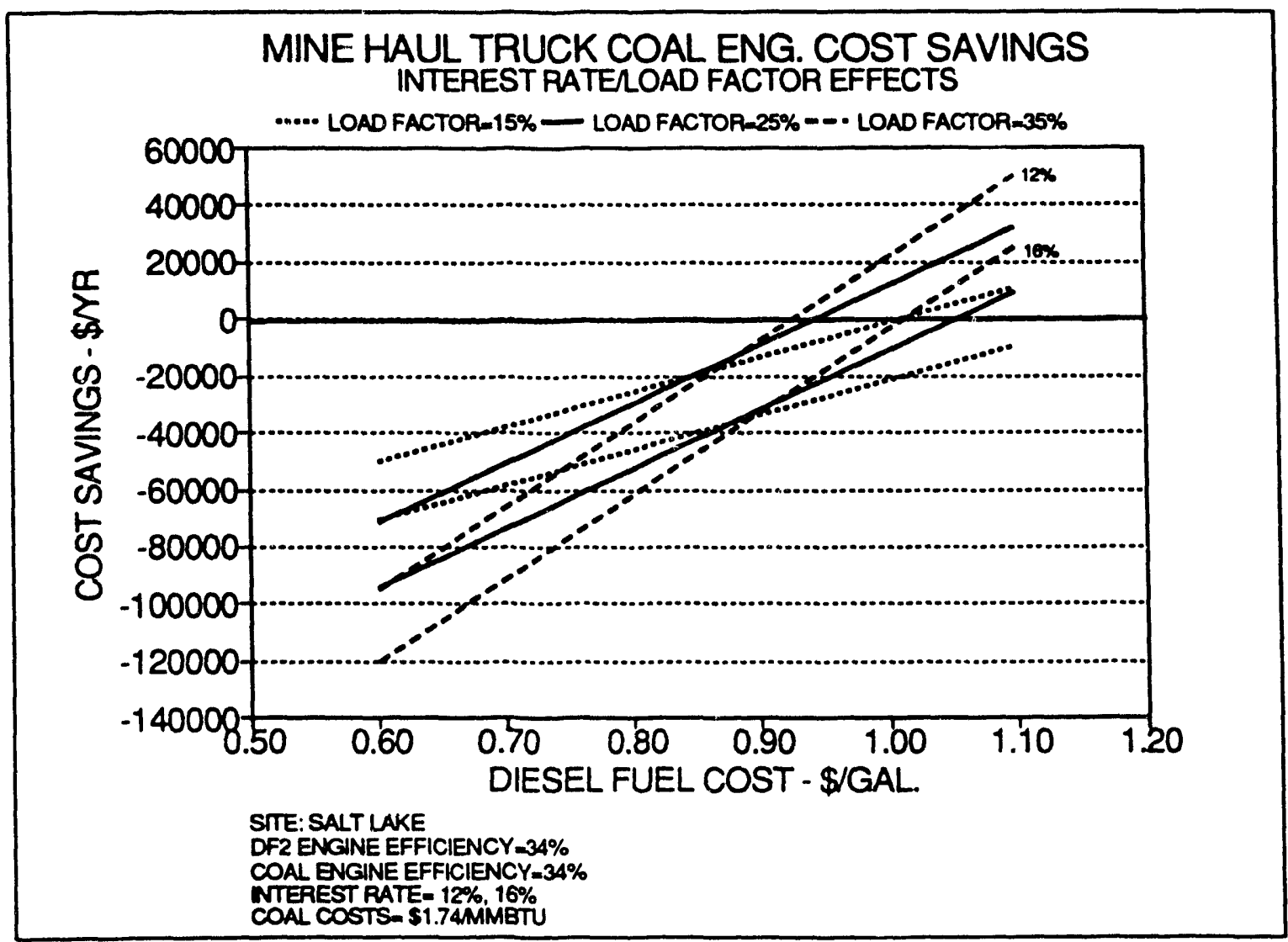




\subsection{Results for Inland Waterway Tow Boat}

The inland waterway tow boat application assumes two 1,000 HP engines. The tow boat engine model results show some impressive annual savings in comparison to the mine-haul truck application, largely because of assumed higher load factors. Pittsburgh was chosen as the refueling site for the tow boat. At estimated slurry costs, the break even diesel fuel cost is reduced to $\$ .82 / \mathrm{gal}$. for a coal engine efficiency of $34 \%$. As the load factor increases from $40 \%$ to $50 \%$, the diesel fuel cost break even cost reduces to $\$ .79 / \mathrm{gal}$. This is quite significant because diesel fuel prices increased to this level in recent years on an intermittent basis.

Figure 15 display the effect on the diesel fuel cost break even point caused by reducing the coal cleaning cost. A reduction in the coal cleaning cost from $\$ 1.21 / \mathrm{MMB}$ tu to $\$ .61 / \mathrm{MMB}$ tu at a load factor of $40 \%$ reduces the diesel fuel cost break even point from $\$ .82 / \mathrm{gal}$ to $\$ .74 / \mathrm{gal}$ for a coal engine efficiency of $34 \%$. Table 25 summarizes the effect on annual cost savings for an assumed diesel fuel cost of $\$ 1.00 / \mathrm{gal}$.

Table 25: Coal Cleaning Cost Effects on Annual Savings for Inland Tow Boat Dlesel Fuel Cost=\$1.00/gal, Coal Englne Efficiency $34 \%$

\begin{tabular}{|c|c|c|}
\hline \multirow[b]{2}{*}{ Load Factor } & \multicolumn{2}{|c|}{ Coal Cleaning Cost (\$MMMBtu) } \\
\hline & $\$ 1.21$ & $\$ .61$ \\
\hline $30 \%$ & $\$ 35,000$ & $\$ 55,000$ \\
\hline $40 \%$ & $\$ 55,000$ & $\$ 80,000$ \\
\hline $50 \%$ & $\$ 75,000$ & $\$ 120,000$ \\
\hline
\end{tabular}

Varying the nozzle life in the engine model gives an indication of the relative effect of maintenance costs of a high wear component of the coal engine. Figure 16 displays the annual savings caused by using a coal engine in place of an oil-fired engine. From a comparison of Figures 15 and 16, it can be seen that a doubling of the nozzle life has a smaller cost savings affect than reducing the coal cleaning in half. For the current estimate for nozzle life of 500 hours and a coal engine efficiency of $34 \%$, the break even diesel fuel cost ranges from $\$ .80 / \mathrm{gal}$. for a load factor of $50 \%$ to $\$ .86 / \mathrm{gal}$. for a load factor of $30 \%$. Table 26 summarizes the yearly savings for the inland tow boat application in Pittsburgh and two nozzle life values of 500 hours and 1,000 hours. 
Flgure 15: Coal Cleaning Cost Effects for an inland Tow Boat

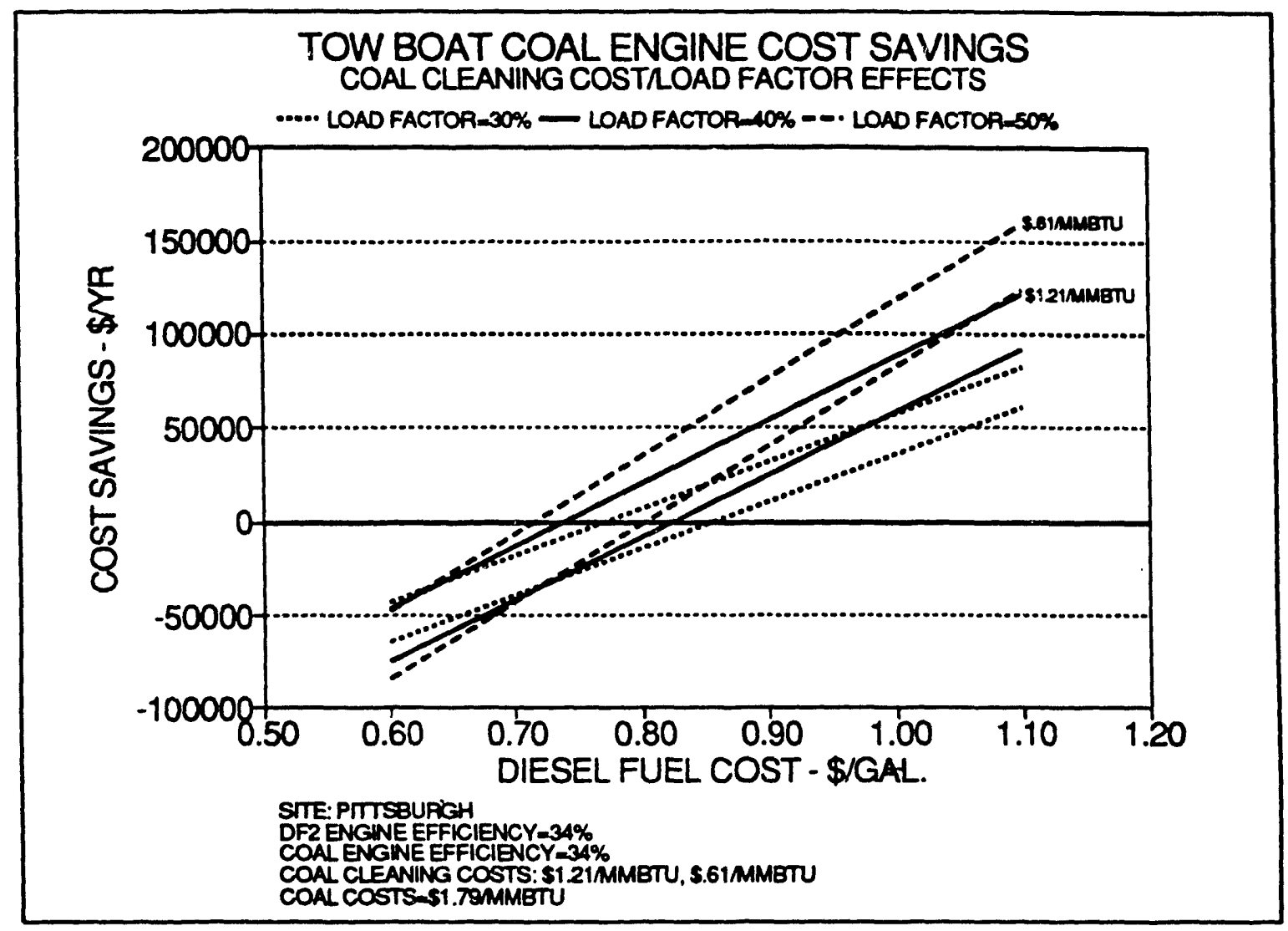

Table 26: Nozzle Life Cost Effects on Annual Savings for Inland Tow Boat Dlesel Fuel Cost=\$1.00/gal, Coal Engine Efflciency $34 \%$

\begin{tabular}{ccc} 
& \multicolumn{3}{c}{ Nozzle Life (Hours) } \\
Load Factor & 500 & 1,000 \\
\cline { 2 - 3 } $30 \%$ & $\$ 35,000$ & $\$ 45,000$ \\
$40 \%$ & $\$ 60,000$ & $\$ 70,000$ \\
$50 \%$ & $\$ 80,000$ & $\$ 98,000$ \\
\hline
\end{tabular}

Varying the financing rate indicates the effect of the cost of money on the annual cost savings generated by using a coal engine in place of an oil-fired engine in an inland tow boat application. At $12 \%$ interest rate, the diesel fuel cost break even point varies from $\$ .77 /$ gal. for a load factor of $50 \%$ to $\$ .81 / \mathrm{gal}$ for a $30 \%$ load factor. Table 27 summarizes the effects on the annual cost savings for the inland tow boat application in Pittsburgh due to interest rates varying from $12 \%$ to $16 \%$. Figure 17 displays the effects on annual savings caused by varying the financing interest rate of the engine. 
Figure 16: Nozzle Llfe Cost Effects for a Mine-Haul Truck

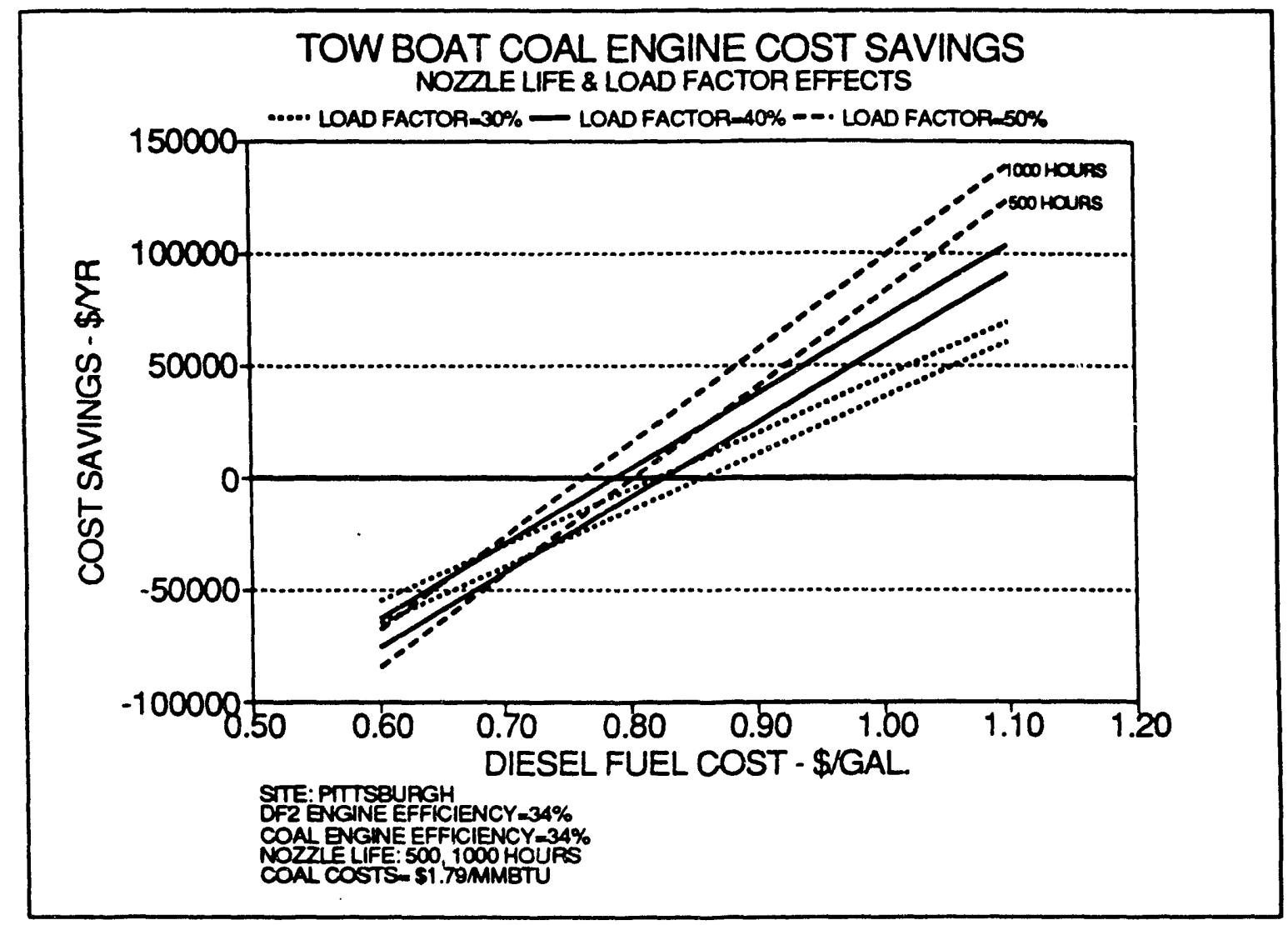

Table 27: Interest Rate Effects on Annual Savings for Inland Tow Boat Diesel Fuel Cost=\$1.00/gal, Coal Engine Efficiency $34 \%$

\begin{tabular}{|c|c|c|}
\hline & \multicolumn{2}{|c|}{ Interest Rates } \\
\hline Load Factor & $12 \%$ & $16 \%$ \\
\hline $30 \%$ & $\$ 48,000$ & $\$ 25,000$ \\
\hline $40 \%$ & $\$ 65,000$ & $\$ 45,000$ \\
\hline $50 \%$ & $\$ 95,000$ & $\$ 65,000$ \\
\hline
\end{tabular}


Figure 17: Interest Rate Effects for an Inland Tow Boat

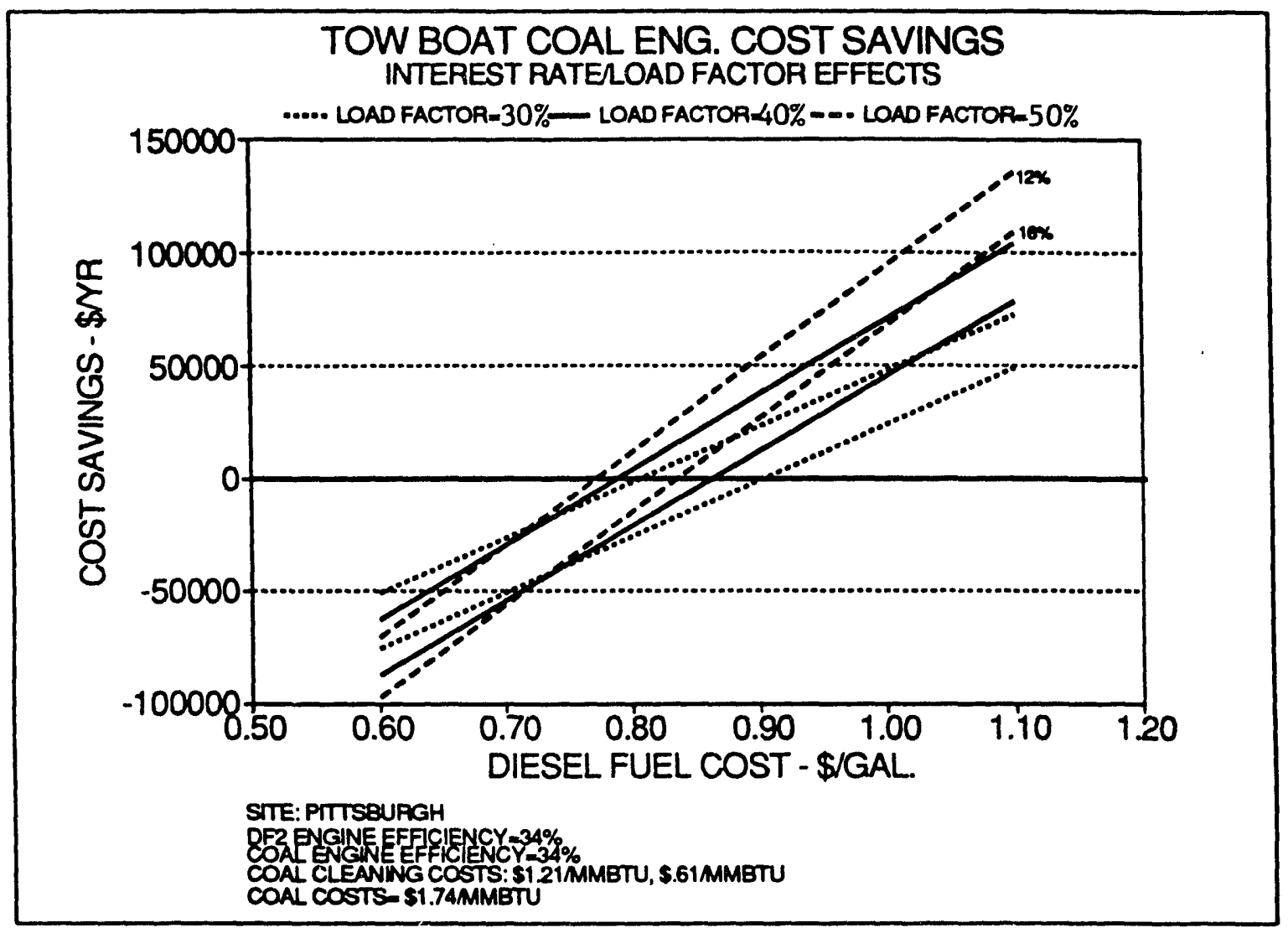

\subsection{Dlesel Fuel Use Effects}

For most of the parametric runs, the engine model assumed that the coal engine uses coal $100 \%$ of the time it is operating. In reality, there is idle mode for the coal engines. The coal engine may use diesel fuel during that time. The engine model spreadsheet was modified to calculate the effect of using $5 \%, 10 \%$ and $20 \%$ diesel fuel. The spreadsheet runs were made assuming the baseline values for all other parameters and was run for the mine-haul truck in Salt Lake City and the inland tow boat in Pittsburgh.

Table 28 summarizes the effect of diesel fuel use on the annual savings for coal engine efficiency of $34 \%$ and a load factor of $25 \%$ for the mine-haul truck. At an efficiency of $34 \%$, the coal engine cost savings break even point ranges from $\$ 1.03 / \mathrm{gal}$. at $5 \%$ diesel fuel use to $\$ 1.09 / \mathrm{gal}$. at $20 \%$ diesel fuel use. Figure 18 displays this graphically.

Table 28: Dlesel Fuel Use Effects on Annual Savings for Mine-Haul Truck Load Factor $=25 \%$, Diesel Fuel Cost $=\$ 1.00 /$ gal, Coal Engine Efficlency $34 \%$ 
Figure 18: Diesel Fual Use Effects for a Mine-Haul Truck

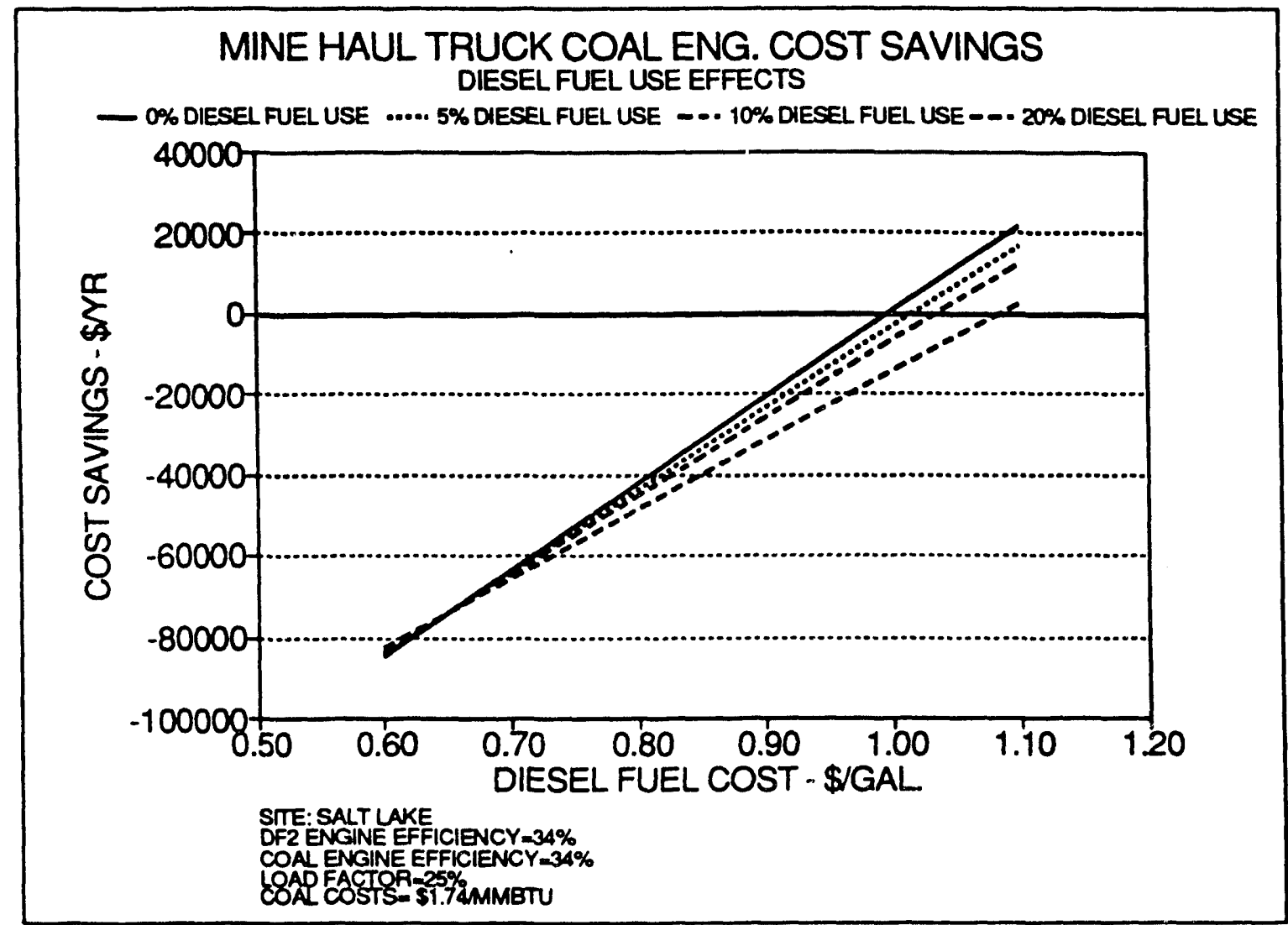

Table 29 summarizes the effect of diesel fuel use on the annual savings for coal engine efficiency of $34 \%$ and a load factor of $40 \%$ for the inland tow boat. At an efficiency of $34 \%$, the coal engine cost savings break even point ranges from $\$ .84 / \mathrm{gal}$. at $5 \%$ diesel fuel use to $\$ .89 / \mathrm{gal}$. at $20 \%$ diesel fuel use. Figure 19 displays this graphically.

Table 29: Diesel Fuel Use Effects on Annual Savings for Inland Tow Boat Load Factor $=40 \%$, Diesel Fuel Cost $=\$ 1.00 /$ gal, Coal Engine Efficlency $34 \%$

\begin{tabular}{lcc}
\hline Fraction Diesel Fuel Use: $5 \%$ & $10 \%$ & $20 \%$ \\
Annual savings: $\$ 28,000$ & $\$ 42,000$ & $\$ 50,000$ \\
\hline
\end{tabular}


Figure 19: Diesel Fuel Use Effects for an Inland Tow Boat with a Coal Engine Efflclency $=34 \%$

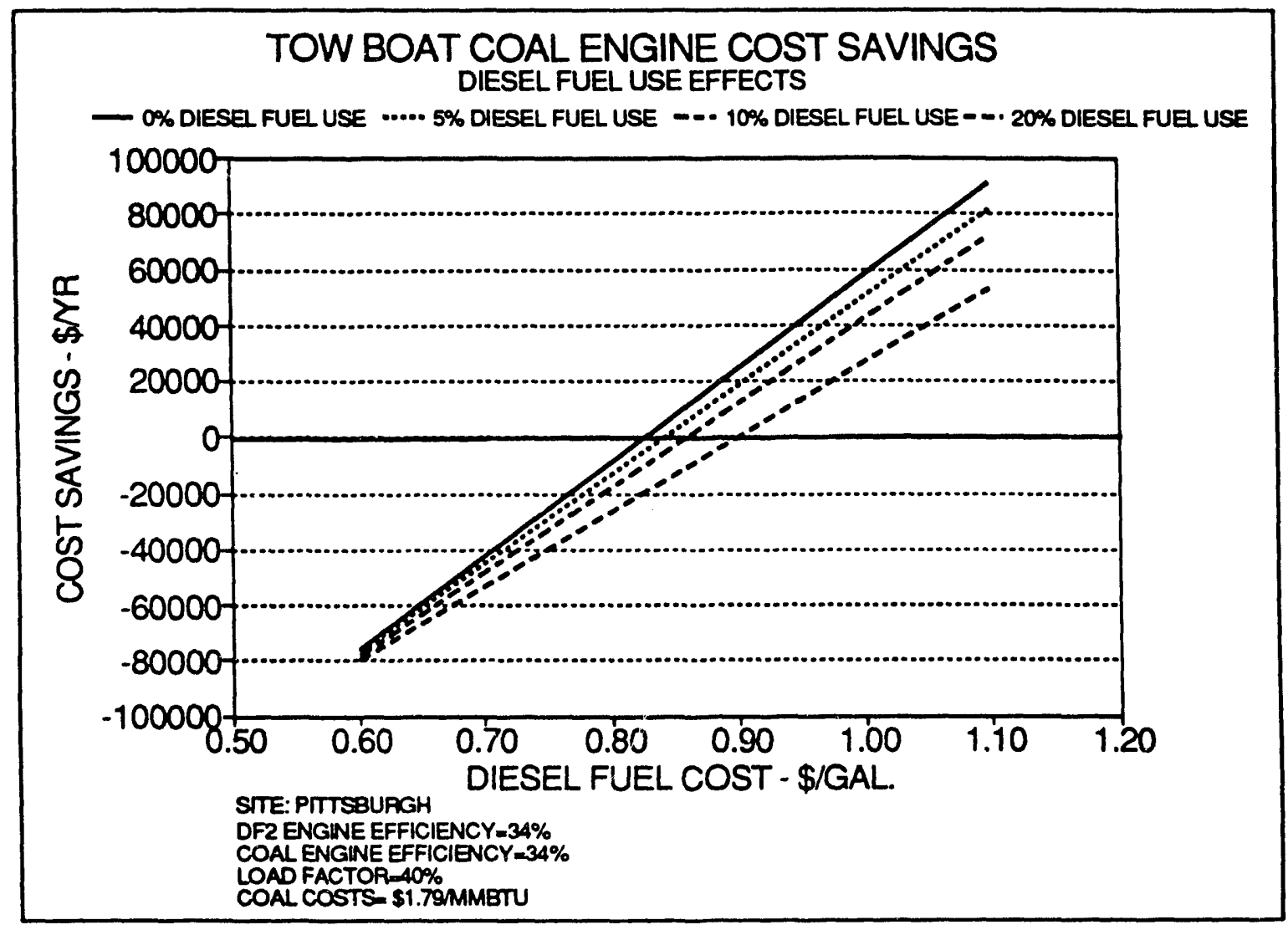

\subsection{Conclusions}

From an economic feasibility standpoint, the use of a coal engine in place of an oil-fired engine appears feasible in the mine-haul truck and tow boat applications and shows significant possibilities ior annual savings (up to $\$ 100,000$ per year for boat or truck). As technology progresses in lowering the costs in the coal cleaning area and improving the engine component wear, it has been shown that the savings over oil-fired engine can be dramatic. It is also important to note that it is anticipated that oil prices will rise faster than coal prices further enhancing the annual savings.

It has been shown that the inland tow boat application has greater savings potential than the mine-haul truck. This is because the load factor on tow boat engines is higher than the mine-haul truck and partly because the Blue Gem coal and slurry plant costs near Pittsburgh is less expensive than those near Salt Lake City. The nationwide potential for displacing fuel oil with coal is also greater for the towboat application. 

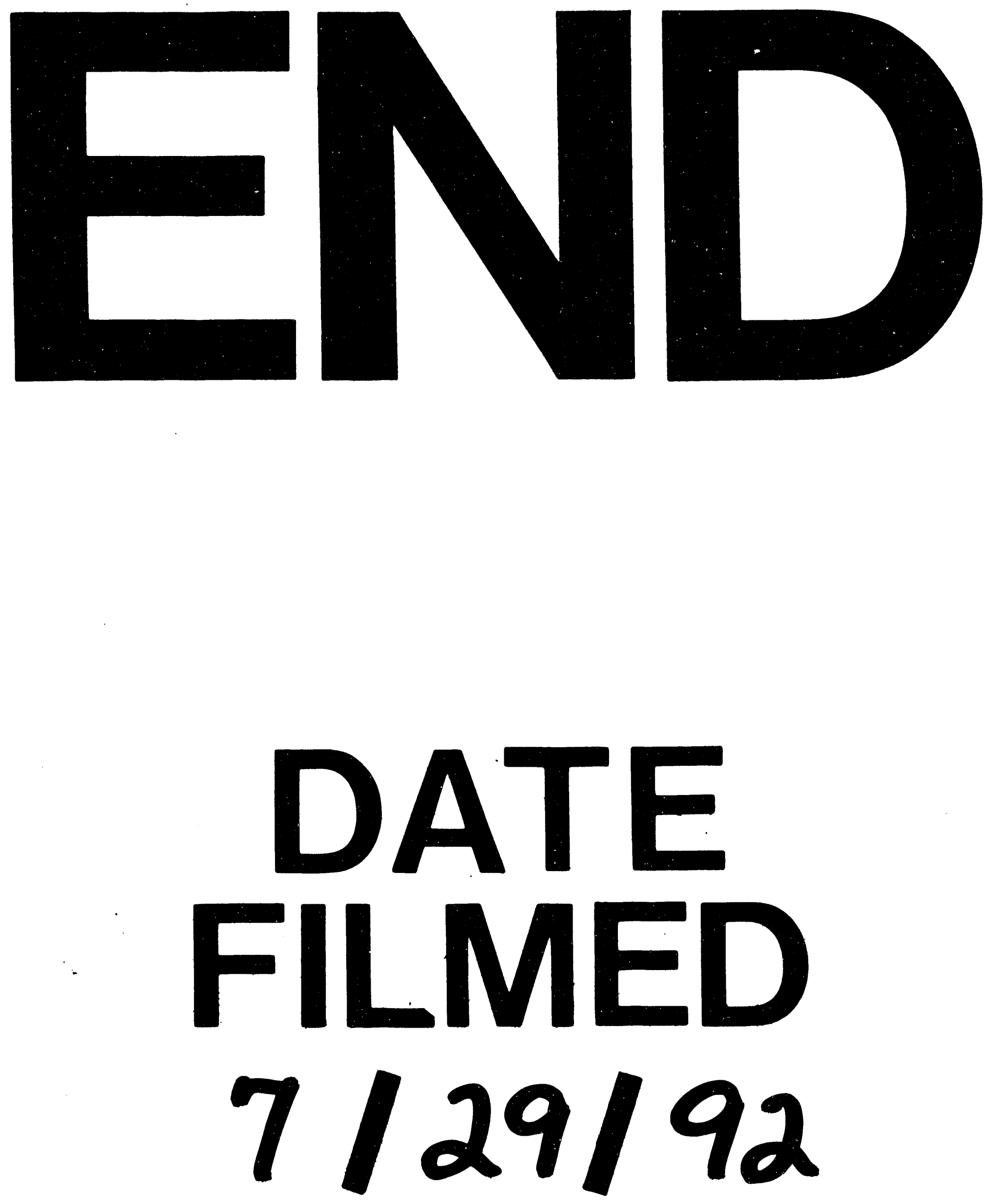

1 
